University of Pennsylvania Carey Law School

Penn Law: Legal Scholarship Repository

Faculty Scholarship at Penn Law

2003

\title{
Corporate Constitutionalism: Antitakeover Charter Provisions as Pre-Commitment
}

\author{
Marcel Kahan \\ New York University Law School \\ Edward B. Rock \\ University of Pennsylvania Carey Law School
}

Follow this and additional works at: https://scholarship.law.upenn.edu/faculty_scholarship

Part of the Business Organizations Law Commons, and the Other Business Commons

\section{Repository Citation}

Kahan, Marcel and Rock, Edward B., "Corporate Constitutionalism: Antitakeover Charter Provisions as PreCommitment" (2003). Faculty Scholarship at Penn Law. 19.

https://scholarship.law.upenn.edu/faculty_scholarship/19

This Article is brought to you for free and open access by Penn Law: Legal Scholarship Repository. It has been accepted for inclusion in Faculty Scholarship at Penn Law by an authorized administrator of Penn Law: Legal Scholarship Repository. For more information, please contact PennlawIR@law.upenn.edu. 


\title{
PRECOMMITMENT AND MANAGERIAL INCENTIVES
}

\section{CORPORATE CONSTITUTIONALISM: ANTITAKEOVER CHARTER PROVISIONS AS PRECOMMITMENT}

\author{
MARCEL KAHAN ${ }^{\dagger}$ \& EDWARD B. ROCK ${ }^{\dagger+}$
}

Constitutions constitute a polity and create and entrench power. A corporate constitution-the goternance choices incorporated in state latu and the certificate of incorporation-resembles a political constitution. Delaware law allows panties to create corporations, to endow them with perpetual life, to assign rights and duties to "citizens" (directors and shareholders), to adopt a great variety of governance structures, and to entrench those choices. In this Article, we argue that the decision to endow directors with significant power ozer whether and how to sell the compary is a constitutional choice of goternance structure. We then argue that it is, on theoretical and empirical grounds, a perfectly intelligible choice: shareholders reasonably might op! for board entrenchment-implemented, for excumpie, by means of a staggered board-in order to enable a board to employ selling strategies more effectively and, thus, to increase the premium shareholders receive when the comparity is sold. Such a decision is a kind of precommitiment wherely shareholders, by binding themselves ex ante, may be able to improze their collective position expost.

After examining how sharpholders an entrench particular goternance structures under Delaware law, we examine two issues that arise once shareholders have chosen to entrench a governance structure: the question of incomplete implementation that arises in cases such as Blasius and Liquid Audio; and the questions of when and whether changed circumstances justify ex post judicial negation of shareholders' prior commitments.

Professor of Law, New York University School of Law.

Saul A. Fox Distinguished Professor of Business Law, University of Pennsylvania School of Law.

We thank W'illiam Allen, Jennifer Arlen, Lucian Bebchuk, Robert Daines, John Ferejohn, Bary Friedman, Joseph Gatto, Larry Hamermesh, Ehud Kamai, Michael Klausner, Lewis Kornhauser, Larry Kaniner, Mark Ramseyer, Larry Ribstein, Eric Tallev, and participants at workshops at Michigan Law School and NYU School of Law and this Symposium for helpful comments. Edward Rock's research was supported by the Institute for Law and Economics, the Saul A. Fox Research Endowment, and the Milton and Miriam Handler Foundation. Marcel Kahan's research was supported by the Filomen D'Agostino and Max E. Greenberg Research Fund. 


\section{INTRODLCTION}

Companies, like many other complex assets, are almost always sold by negotiation. The hostile tender offer, so beloved by corporate law scholars, has never been a major mode for control transactions. This Article focuses on three interrelated issues: why rational shareholders, aware of the full range of agency costs, might commit to have their company sold through a negotiated process controlled by the board; how they implement this preference; and how courts or legislatures should deal with claims that commitments either have not been properly implemented or have backfired and should be set aside. As such, this is an article about "corporate constitutionalism," about the governance commitments made by shareholders, and about how Delaware deals with these commitments in a dynamic world.

A scene from the real world may help frame our argument. In 1991 , when its stock was trading at around $\$ 20$ per share, Neutrogena, the niche soap maker, put itself up for sale.' Dissatisfied with the interest in the company, CEO and controlling shareholder Lloyd Cotsen took Neutrogena off the market and continued to pursue its expansion strategy." Three years later, when Neutrogena was again put on the market, Johnson \& Johnson bought it for $\$ 35.25$ per share." Wrote the Netw York Times, "Though the price of $\$ 35.25$ a share, more than three times 1993 sales, is high, analysts said Neutrogena`s strong brands and its untapped overseas potential were worth the price."

The Neutrogena case is hardly unique. A board may seek the sale of a company, find market conditions are not right, pull back, and then two or more years later, go to market again and get a "blow away" price. This can be because economic conditions or industry conditions have improved, because the business has done better, or because buyers have just decided the acquisition is "strategic." Often it is not generally known that the company has been up for sale previously.

What one does hear about, however, are cases in which a hostile bidder approaches the company and the board refuses to sell because, it says, conditions are not right. These events have generated, and continue to generate, substantial controversy. Most of the commentary on hostile takeovers falls in one of two broad schools of thought.

'Streetwalker; FORBEs, Sept. 12, 1994, at 288, 289.

"Cotsen's family owned around forty-five percent of Neutrogena's shares. Sallie Hofmeister, Johnson lo Arquire Neulrogena, N.Y. Tines, Aug. 23, 1994, at D 1. 
The Hamiltonian "board veto" school holds that shareholders are not well-equipped to make the decisions involved in the sale of the company and should thus leave these decisions to the board. Believing both in the correctness of their views and in the inability of shareholders to grasp that correctness, board veto proponents are quick to call for legal intervention when shareholders are unwilling on their own to grant to the board the powers demanded.

The Jacksonian "shareholder choice" school holds that boards are self-interested in responding to hostile bids and that shareholders should independently determine whether to accept or reject an offer. But most shareholder choice advocates have no deeper commitment to shareholder autonomy than do board veto proponents. When shareholders consent to rules that enshrine board power, they call for legal intervention to set these rules aside."

By contrast, we believe that shareholders should be taken seriously, not only when deciding on an actual bid, but also when setting up the rules as to who decides.' When shareholders entrench some power in the board (and when they do not)-through a shareholder vote or an investment decision when a company goes public-courts and legislators should presumptively respect that decision. As we argue, neither the theoretical arguments for shareholder choice and board veto nor the empirical eridence are strong enough to overcome

"See, e.g., Martin Lipton, Pills, Polls, and Prefessors Redux, 69 L. CHI. L. Rev. 1037, 10.5()$-58$ (2)(02) (arguing that boards should be permitted to block bids that shareholders want to accept); Martin Lipton, Takenver Bids in the Target's Boardioom, 35 BLS. L.III: 101, 10+ (1979) (same) [hereinafter Lipton, Takeover Bidls].

See, e.g., Lucian Arve Bebchuk, John C. Coates IV \& Guhan Subramanian, The Pinterful Antitakeove' Forre of Staggered Boards: Theory, Evidence, and Policy, 54 STAN. L. REv: 887, 949 (20)2) [hereinafter BC\&S] (arguing that shareholders should not be permitted to adopt an antitakeover device, such as staggered boards, that does not allow for a one-time, up-or-down referendum on acquisition offers); Bernard Black \& Reinier Kratkman, Delaware's Takeover Law: The Lncertain Search for Hidden Talue, 96 Vil. L. L. REV. 521, 561 (20)(1)2) (arguing that courts should not respect staggered board terms because " $[n]$ either the finance literature nor the norms of corporate law support vesting such unbalanced power in the hands of the board"); Ronald J. Gilson, The Case Against Shark Repellent Amendments: Structural Limitations on the Enabling Con(ept, 34 STAN. L. REV. 775, 822-27 (1982) (arguing that, due to shareholder ignorance. shark repellent amendments should be held invalid even if they are approved by shareholders).

We are not the first to make this general point with regard to takeovers. See generally Barry D. Baysinger \& Henry N. Butler, Antitakeouer Amendments, Manngerial Entrenchment, and the Contractual Theory of the Comporation, 71 VA. L. REv. 1257 (1985) (endorsing shareholder-approved antitakeover charter amendments, but opposing antitakeover statutes); Roberta Romano, The Political Economy of Takeover Statutes, 73 V.L. L. REI. 111 (1987) (same). 
that presumption on a wholesale basis. Companies should thus be free to set up their om regine. Moreover, companies may adopt some intemediate regime between shareholder choice and board reto-an opportunity that Delaware law affords and many companies exercise.

The remainder of this Article is organized as follows: in Part I, we identify two aspects of the decision to sell the company-determining its value, and devising and implementing a selling strategy. As we explain, the selling strategy is an integral element of a sales mechanism.

In Part II, we analyze different paradigms for the allocation of decision-making power when a public firm receives an acquisition offer. The classic debate has been dominated by Hamiltonian proponents of the board veto school and Jacksonian proponen ts of shareholder choice. We describe the tradeoffs between these two regimes and put forward and defend a third, Madisonian, option of corporate constitutionalism. Specifically, we argue that shareholders may rationally entrench board pover because shareholders on their own cannot pursue an effective selling strategy."

Part III examines how constitutional choices are implemented. In Delaware. companies have great flexibility in their constitutional choices: through proper charter or bylaw provisions they can entrench board structure and shareholder rights inter se and choose different clegrees of entrenchment. For example, board power can be entrenched, in declining degrees, through differential voting rights, staggered boards, or barriers to shareholder removal of directors between anmual meetings.

Part IV reviews the empirical evidence regarding these entrenchment modes to determine whether it points to the general superiority of a particular decision-making paradigm. We discuss the esidence regarding antitakeorer provisions in initial public offerings (IPOs), the effect of staggered boards on hostile bids, the effect of poison pills on takeover prenia, legislatively imposed staggered boards, and shareholder votes on staggered boards. We conclude that the

We are not the only authors to note and discuss the role of precommitments. Site, e.g. Jennifer Arlen de Eric Talley, Lnregulable Defenses and the Perils of Shartholder

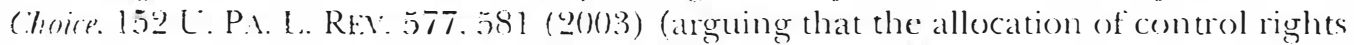
will affect manger decisions ex ante): 1 smn A. Stout, The Shareholder as (hisses: Emprivical

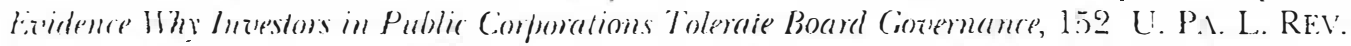

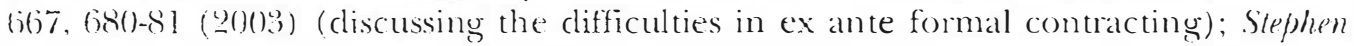

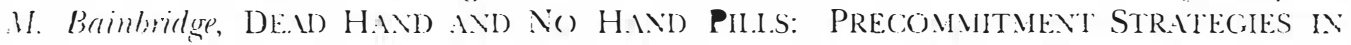

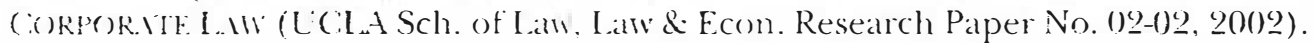


empirical evidence does not support an imposition of shareholder choice or board veto as a mandatory governance structure.

Part $\mathrm{V}$ addresses two issues that arise once shareholders choose to entrench a governance structure. First, we examine the problem of incomplete implementation: when the board left a loophole in the governance structure and a bidder tries to take advantage of it, how should the courts view last-minute attempts to close the loophole? Second, we address the claim that changed circumstances-in particular, the judicial sanctioning of the poison pill-justify a legal bailout of shareholders from their choice to entrench the board through a staggered board. While we conclude that a wholesale judicial bailout is not warranted, we argue that there may be a plausible case for a narrowly targeted legislative bailout structured to minimize transaction costs and the loss of commitment value.

\section{SELI.ING THE FIR.M}

Buying and selling firms is a complicated undertaking, out of which investment bankers and other professionals make a good living. It is as much an art as a science, with experience providing much of the instruction. In this Part, we identify two aspects of the decision to sell a company: determining the value of the company as an independent entity; and devising and implementing a selling strategy. We place particular emphasis on the latter aspect, which we believe has not been properly emphasized in the takeover literature.

In deciding whether to sell an asset, an owner must first consider the value of the asset if it is not sold and how much effort to expend in determining that value. The value of the asset if not sold forms a floor to the price the owner would be willing to accept for the asset under any circumstance-the reservation price.

Second, the owner must consider its selling strategy. By selling strategy, we mean any action designed to increase the price for the asset beyond the reservation price. A selling strategy can, among other things, entail choosing the time to sell, soliciting offers from other bidders or threatening to do so, haggling over price, disclosing information to bidders, rejecting an offer, making "take-it-or-leave-it" counter-offers, or misrepresenting one's willingness to sell.

From the owner's perspective, devising and implementing a good selling strategy is very important. While knowing the reservation price protects the owner against suffering losses from selling the asset, it is the selling strategy that determines how much the owner will profit from a sale. A well-designed selling strategy will usually entail the 
owner rejecting some offers that exceed her reservation price in order to induce better offers-even though this entails a risk of not selling the asset."

As further discussed below, a shareholder choice regime can have the practical effect of inducing a company to auction itself to the highest bidder after it receives an offer above the reservation price. It is thus important to note that such an auctioning regime is not likely to be the optimal strategy for selling the company. For one, an auction may not be the optimal sales mechanism for a firm. Whether an asset is best sold in an auction or by some other mechanism-such as a one-on-one negotiation or sequential search-depends on factors such as the number of potential buyers and the distribution of their valuations for the asset, ${ }^{10}$ the cost to the seller of locating potential buyers, " the cost to buyers of investigating the asset," and the seller's information about such valuations." "The "winner's curse" further complicates the choice: the more bidders there are, the more conservative sophisticated bidders are likely to be in bidding. '"

A nonauction mechanism is likely to be particularly appropriate for the sale of a firm. First, potential acquirers face substantial costs in

See, e.g., Robert Wilson, Repulations in Games and Markels, in G.MLE-THEoretis: MODElS OF BARGAINING 27, 31 (Alvin E. Roth ed., 1985) (noting that the optimal strategy in a simple sequential bargaining model mas involve rejection of a farorable offer); Carl Ehrman \& Michael Peters, Sequential Selling Mechanisms, 4 J. Ec(o): THEORY 237, 238-39 (1994) (presenting a model in which optimal selling strategy is a modified fixed price scheme); R. Preston McAfee \& John McMillan, Searh Mechanisms, 4 J. ECON. THEORY 99, 107-18 (1998) (deriving buyer's optimal sequential search strategy. with a price below buyer's reservation price); John Riley \& Richard Zeckhauser, oprimal Selling Strategies: When to Haggle, When to Hold Firm, 98 Q. J. EC().1. 267, 27() (1983) (deriving an optimal strategy which involves take-it-or-leave-it offers above seller"s reservation price).

11) See Peter Cramton \& Alan Schwartz, Lsing Aurtion Theory to Inform Takeoner Regulation, 7 J.L. ECON. \&. ORG. 27, 5()-51 (1991) (arguing that auctions are inappropriate when bidders have common value).

$"$ See McAfee \& McMillan, supra note 9, at 100-() l (1988) (showing that a sequential search mechanism is optimal when a monopsonist facing costs is dealing with sellers); see also Charles J. Thomas \& Bart J. Wilson. A Comprarison of Auclions and Mullilateral Negotiations, 33 RAND J. E(:0). 140, 145-5) (20(5)2) (comparing prices between auctions and multilateral negotiations depending on number of counter-parties).

12. See Kenneth R. French \& Robert E. McCormick, Sealed Bids, Sunk Costs, and the Process of Competition, $57 \mathrm{~J}$. BL's. 417, 431-33 (1984) (arguing that negotiations may be superior to auctions when bidders face estimation costs).

1.3 See. Michael A. Arnold \& Steven A. Lippman, Selecting a Selling Institulion: Auctions Versus Sequential Search, 33 ECON. INQLIRI 1, 21 (1995) (showing that sequential search is superior to auctions when the number of units sold is small).

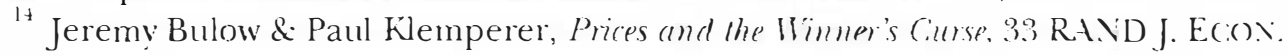
$1,2(2()() 2)$. 
deciding whether to make an acquisition offer for a company. ${ }^{15}$ Such costs make potential bidders reluctant to enter an auction and, to the extent that bidders do enter, reduce the equilibrium price for which the company can be sold. ${ }^{16}$ Second, bidding firms that fail to acquire a target experience substantial declines in their stock price. ${ }^{17}$ The prospect of such declines may further increase bidders' reluctance to enter an auction. Third, in an auction, the target company typically provides confidential information to all bidders. ${ }^{1 \times}$ Thus, at least two bidders, who are often competitors, have intimate information about substantial assets that one of them is about to acquire. This fact may well reduce the value of the target to both bidders and, accordingly, the price each would be willing to pay. "Indeed, closely held companies are generally sold in negotiated transactions, rather than by auction. And even though corporate law rules tend to encourage auctions when a public company is sold, such auctions ensue infrequently and when they do occur, almost never draw more than two bidders.

Even when an auction is optimal, ${ }^{20}$ the optimal auction format generally involves an owner setting a minimum bid that exceeds the owners' reservation price. ${ }^{.1}$ This bid requirement, ex ante, serves to

1. See Marcel Kahan \& Michael Klausner, Lockups and the Market for Corporate Control, to STiN. 1. REV. 1539, 1547 (1996) (analyzing the effect of prospective bidders' costs on their likelihood of making a bid).

1" See French \& McCormick, supra note 12, at $128-29$ (describing the effect of entry fees on the value of the winning bid); see also Barry E. Adler, A Theory of Corporate Insolrency, 72 N.Y.U. L. REV. 343, 355 (1997) (stating that sellers indirectly absorb bidders preparation expenses through lower sale price).

${ }^{17}$ See Patul Asquith, Merger Bidls, (Incertainty, and Stockholder Returms, 11 J. FIN. ECON. $51,75-76$ (1989) ("[U]nsuccessful bidding firms have significantly negative excess returns immediately after the outcome clate and throughout the first year.").

is Sep, e.g. Mills Acquisition C.o. v. Macmillan, Inc., 559 A.2d 1261, 1279-80) (1989) (subjecting differential treatment of bidders to strict judicial scrutiny).

Bidders will generally sign confidentiality agreements prohibiting them from using confidential information for any purpose unrelated to the bid. While such agreements mar well be effective in assuring that a bidder does not disclose the information to a third parts, they are unlikely to be effective in assuring that the bidder does not use it internally:

¿ne Se, e. Jeremy Bulow \&. Paul Klemperer, Auctions Versus Negotiations, 86 AM. E(O). Rev. 180, 187-89 (1996) (deriving certain conditions in which auctions are superior to negotiations); Arthur De Vany, Institutions for Stochastic Markets, $143 \mathrm{~J}$. INSITIUTIONAL \& THEORE TICAL ECON. 91, 94-10)(1987) (comparing auctions to posted price, sequential search selling); Ruqu Wang, Autions Versus Posted-Price Selling, 83 A.M. EC:()). REV. 838 , 844-47 (1993) (showing that superiority of auction to posted-price selling depends on costliness of auction and steepness of marginal revenue curve).

2I See R. Preston Mcifee \& John McMillan. Auctions and Bidding, $25 \mathrm{~J}$. EcoN: LITERLTLRF 699, 713 (1987) (showing that, for a broad family of action rules and regardless of the number of bidders, a seller maximizes its revenue by announcing that it 
increase the owner's surplus when only one bidder is willing to pay that price (though it can result, ex post, in the owner refusing to sell at the highest bid, even if that bid exceeds her own valuation). Moreover, an owner would want to control the timing of an auction, rather than permit an interested buyer to force the owner to conduct an auction. Indeed, given that a buyer wishes to acquire the asset at the lowest price possible, it is likely to choose the worst possible time for an auction from the perspective of the owner. Thus, even in an auction setting, an owner would want discretion in devising the rules of the auction.

\section{WhO DECIDES? HAMILTONIANS, JACKSONIANS, AND MADiSONIANS}

The classic debate on how a publicly traded company should decide whether to accept an acquisition offer has been dominated by two schools of thought. According to one group of scholars, it is the elected representatives of shareholders entrusted with the management of the company-the board of directors-whose approval should always be necessary to sell a company. ${ }^{2 .}$ Boards, in other words, should be able to veto an acquisition offer in order to protect shareholders from their own bad decisions. Since this school maximizes the authority of the shareholders' representatives, while according only a narrow role to the shareholders themselves in corporate decision making, we follow U.S. constitutional theory and refer to it as Hamiltonian."

According to a second group of scholars, it is the shareholders as owners of the company who should, at any time, be able to sell the

will not accept bids with a reserve price that is always strictly greater than the seller's personal value of the object); John (B. Riley \& William F. Samuelson, Optimal Auctions, 71 A.M. Ec:ON. REV. 381, 382 (1981) (finding the same result).

"2: See Lipton, Takeover Bids, supra note 5, at 120) ("[W'] accept the premises that the directors of a target do not have an absolute duty to accept a takeover bid and that there is no absolute requirement that the question be referred for direct action by the shareholclers."); see also Richard E. Kihlstrom \& Michael L. Wachter, Corporate Policy and the Coherence of Delazuare Takeoter Laum, 152 L. PA. L. REv. 723, 726 (20)3) ("[M] anagement discretion is arguably the appropriate standard for takeover defenses ....").

Sep Doron Ben-Atar \& Barbara B. Oberg, Introduction: The Paradoxical Lepary of the Federalists, in Federailsts Reconsidered 1, 7-9) (Doron Ben-Atar \& Barbara B. Oberg eds., 1998) (discussing the Federalists' elitism and aversion to participatory politics); see also James P. Martin, When Repression Is Democratic and Constitutional: The Federatist Theon of Representation and the Sedtition Aat of 1798, 66 L. CHI. L. REv. 117, $134-43$ (1999) (arguing that the Federalists' theory of representation was undemocratic). 
company, whether or not the board approres of the sale." Shareholders, in other words, should have uninhibited choice in deciding on an acquisition offer. Since this school sees the board as a derice designed to implement the present will of shareholders, we will refer to it as Jacksonian."

In the first Part, we will lay out the arguments put forward by the Hamiltonians and the Jacksonians. We will then articulate a third approach that has been less prominent in the classic debate. According to the third school, there are benefits and costs to both board veto and shareholder choice. Shareholders may thus decide to delegate limited or full veto power to the board. Since in this approach shareholders may, at least to some degree, rationally entrench board power. we will refer to it as Madisonian. "We conclude this Part with a brief discussion of the divergence between those rules that are privately optimal for shareholders and those that are socially optimal.

\section{A. Board Veto: The Hamilionians}

The classic Hamiltonian argument for board reto rests on the board's superior ability to assess the value of the company. Boards will typically possess nonpublic information about company value. For example, Richard Kihlstrom and Michael Wachter argue in this Symposium that boards possess superior information about project risk and, thus, about the proper rate at which expected cash flow's are to be cliscounted. ${ }^{27}$ Moreover, shareholders, because they are excessively oriented towards the short-term or just misperceive reality, fail to appreciate fully the board's informational advantage.

"t See Frank H. Easterbrook \& Daniel R. Fischel, The Proper Role of a Target's Marn-

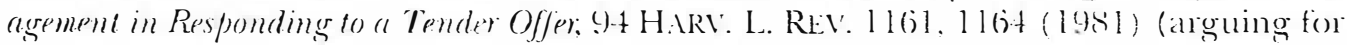

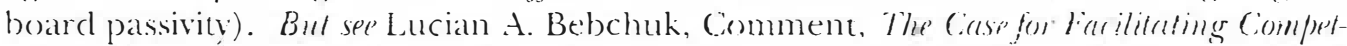
ing Tender Offers, 95 HART. L. REV. $1028,1050-56$ (1982) (a iticizing Falsterbrook and Fischel's article and arguing for limited board discretion to solicit competing bids);

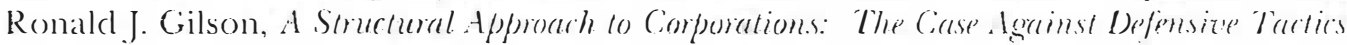
in Tender Offers, 33 STAN. L. REV. 819. s21 (1981) (same).

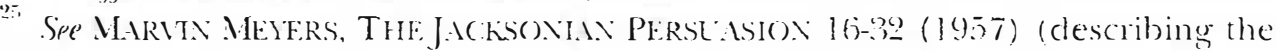

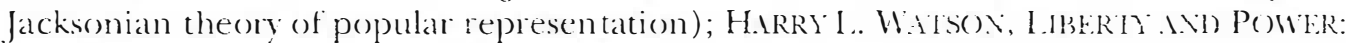

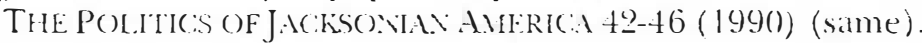

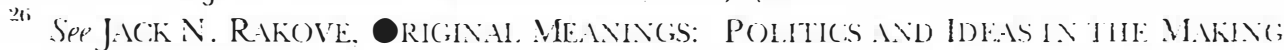

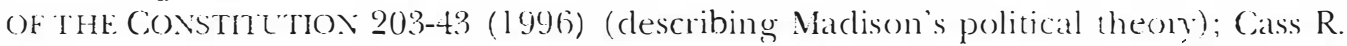

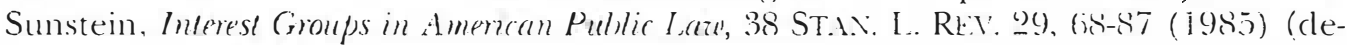
fining the Madisonian conception of politics and representation).

Kihlstrom \& Wachter, sufuanote 22, at 542-45.

As discussed below, another argument for granting the benat some decisionmaking power is related to the board's superior ability to implement a selling strategr. 
Hamiltonians also have little faith in the adequacy or efficacy of the board disclosing information to shareholders. Some corporate information cannot be disclosed without destroying the value of the information to the company. Other information is complex, and shareholders-being dispersed and lacking proper expertise-may not fully grasp its significance. ${ }^{.9}$

Finally, Hamiltonian proponents of board reto are not greatly concerned about agency costs: the possibility that boards may oppose offers to maintain control and the related emoluments, or other selfserving reasons. Because boards have a superior assessment of the value of the company and cannot directly communicate the basis for

See discussion infra Part II.C. In addition to takeover-related reasons for entrenching board power, there may be other important non-takeorer-related reasons. Indeed, these other reasons may potentially outweigh the takeover-related considerations. First, entrenchment may be warranted because it enables a party to make a credible commitment not to hold up third parties from whom it seeks certain actions. Sep Eric A. Posner \& Adrian Vermeule, Legislative Entrenchenent: A Reatpraisal, 111 Y.LLE. L.J. $1665,167(1)-73$ (20)(2) ) (analyzing entrenchment of legislation by supermajority vote requirements). Entrenchment can thus make it easier and cheaper for a party to control its relations with other entities. In the corporate context, this entrenchment may be valuable both intrafirm and interfirm. In the intrafirm context, entrenchment of management may be valuable in inducing managers to invest in firm-specific human capital. Sep. e.g.. David D. Haddock, Jonathon R. Macey \& Fred S. McChesney, Property Rights in Assets and Resistance 10 Tender Offers, 7.3 VA. L. Rev. 701, 712-17 (1987) (explaining the importance of management's protection of existing "quasi-rents" of human capital). In the interfirm context, a joint-renture partner, because of the notorious fragility of joint ventures, may enter into a joint venture on more favorable terms if it has assurance that it will be dealing with the management team it contracted with. Alternatively, it may be that a joint-venture party will be willing to enter into a joint venture with a non-competitor but not with a competitor. One way to hatndle this problem is to make the joint venture terminable upron a change of control or if a partner is acquired by a competitor of the other partner. This, however, may jeopardise investments specific to the joint venture. Entrenched board power (e.g.. in the form of a staggered board ) may provide the requisite assurance more cheaply. A need for at commitment not to hold up third parties is also the reason why one would want to entrench a rule not to solicit alternative bids, as suggested by board passivity proponents. See id. at 728-30) "Lnlike the Easterbrook-Fischel proposal simply to ban resistance, a bond-enforcing rule would not bring with it the risk of firms losing the benefits of bargaining ....").

Second. entrenchment can be valuable because it permits agenda control. One can remore contentious issues from the agenda in order to focus on other business. For example, "board deference" may allow the participants in the firm to get one issue off the agenda (e.g., change of control), while focusing on other business (e.g., restructuring the finm. building a new widget, building a better widget, etc.).

" Once a bid is made, the presence even of an efficient stock market will not much assist shareholders in evaluating newly disclosed information, since the market price is strongly affected by the market's expectations about the bid, rather than by the free-standing value of the company. 
their assessment to shareholders, and because boards are believed to act in the interest of shareholders. Hamiltonians believe that boards should have veto power over acquisition offers.

\section{B. Shareholder Choice: The Jacksonians}

The Jacksonian case in favor of shareholder choice rests on the presence of agency costs. Managers, it is argued, obtain private control benefits that they would lose if the company were acquired. To protect these benefits, managers are inclined to resist bids even when it is in the interest of shareholders to accept the bid. Moreover, the threat of being ousted in a takeover induces managers to run the company more efficiently initially. In order to assure that managers do not block takeovers that are beneficial to shareholders, and do not use their ability to block takeovers to insulate themselves from the disciplining forces of the takeover market, it is imperative that shareholders can independently decide whether to accept an acquisition offer." The board's role should be confined to providing information to shareholders and, according to some, to soliciting other offers and thereby stimulating an auction. Jacksonians would thus greatly limit the board's power to choose the selling strategy. In particular, a board would not be permitted to resist a bid, except, as some argue, by auctioning the company to the highest bidder, without setting a minimum premium, at a time chosen by the hostile bidder.

Jacksonians admit that boards may have superior information about company value, and may even concede that boards cannot always communicate this information to shareholders. Such shareholder ignorance alone, however, does not justify giving the board an entrenched veto power. A board endowed with superior information, Jacksonians argue, could just advise shareholders that an acquisition offer is too low and should be rejected. If that advice is credible, shareholders (realizing the board's superior information) will follow it." The Hamiltonian position that shareholders need to be protected from making bad decisions by giving the board an entrenched veto requires not just that shareholders are comparatively ignorant about

St' See, e.g., Cilson, supra note 24 , at $845-48$ (discussing the argument that shareholders should decide whether to accept or reject a tender of fer).

$: 3$ See e.g. Lucian Arye Bebchuk, The Case tgrainst Board Veto in Comporale Takeners, 69 L. C.H. L. RFI: 973, 999-1)(1)1 (2002) (explaining that "target managers of ten have private information, both hard and soft, that public investors do not possess"). 
company value (which Jacksonians may concede), but that they also fail to realize their own limitations (which Jacksonians dispute).

\section{Corporate Constitutionalism: The Madisonians}

According to the Madisonian school of thought (which we will elaborate here), shareholders mav rationally endow the board with some entrenched power in deciding whether and how to sell the company." The Madisonian position differs from the Hamiltonian and Jacksonian ones, and presents a middle ground between them, in two respects. First, unlike the Hamiltonians, Madisonians view shareholders as capable of making intelligent decisions on acquisition offers. However, unlike the Jacksonians, Madisonians do not conclude that shareholders should never rationally entrench power in the board. Second, Madisonians do not argue that the same regime is optimal for all companies, and accept that intermediate regimes, in which board power is entrenched to a limited degree, may be desirable.

In our assessment, the strongest argument for according decisionmaking power to the board is not the board's superior ability to assess company value, but rather the board's superior ability to determine and implement a value-maximizing selling strategy. There are

Several other commentators have suggested that granting the board power ores acquisition decisions may increase firm value without relying on shatreholders' irrationality. See, e.g., Arlen \& Talley, supra note 8 , at 565 (concluding that a shareholder choice regime may lead boards to adopt undesirable embedded defenses prior to a takeover bid); Baysinger \& Butler supra note 7 , at 1.302-(03 (arguing that, if other control mechanisms function properly, antitakeover provisions may reduce costs associated with a corporate control market); Stout, supra note 8, at $7(1) 9-1()$ (proposing that commitment to board veto power may promote team production); see also Romano, supra note 7 , at $128-41$ (arguing that certain antitakeover provisions art in the interest of small shareholders).

Previous commentators who have noted that antitakeover devices may enhance the target's bargaining power include: Bebchuk, supra note 31, at $10(1) 7-() 9$ (noting that management may have an advantage over shareholders in bargaining situations because shareholders are dispersed); John C. Coates IV, Explaining Variation in Takeouer

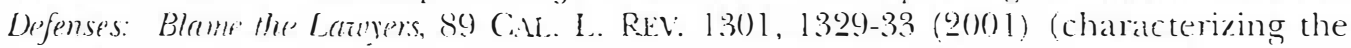
bargaining power hypothesis as an ex post justification); Robert Daines \& . Michael Klausner, Do IPO Chaters Maximize Firm Galue? Antitakenter Protedion in IP(Os, $17 \mathrm{~J} . \mathrm{L}$. Ecox. \& OR(;. 83, 89) (2001) (asserting that "[w] here bidders face actual or potential competition in bidding for a target, this collective action problem [of inducing shareholders to accept a bid when holding out would be more beneficial] is absent"): Harry DeAngelo \& Edward M. Rice, Anfilakenter Charter Amendments and Storkholder Wealth, 11 J. FIN E(O) 329. 335 (1983) (noting that private incentives for individual shareholders to tender result in collectively subuptimal tendering decisions because individual shareholders will "attempt to appropriate the premium offer in a tender bid for' 
several reasons for this superiority and why it may lead companies to entrench some decision-making power in the board.

First, picking a selling strategy involves subtle and complex decisions. ${ }^{31}$ Should one solicit a competing bid? Should inducements be offered to other bidders? Should one make a counter-proposal and if so, at what level? Determining a proper strategy and implementing it is costly and may require coordinated action. Public shareholders are ill-equipped to bear these costs and engage in such coordination.

Second, a selling strategy often requires a level of secrecy that shareholders are unable to maintain. Even if shareholders could communicate at low costs, communications among a large group of shareholders are unlikely to remain confidential. Moreover, federal law requires disclosure of certain shareholder communications. ${ }^{36}$ Shareholders therefore, would have difficulty coordinating with each other without disclosing their strategy to the bidder.

Third, shareholders wear their reservation price on their sleeves. Their assessment of the value of their shares-the market price at which the stock trades-is readily available. But when the stock trades for ten dollars, shareholders may have difficulty persuading a bidder that they would refuse any offer below, say, twelve dollars a share. By

corporate control"); Hacldock, Macey \& McChesney, supra note 28, at 740) (arguing generally that the board passivity rule may be undesirable as it precludes bargaining); Dale A. Oesterle, The Viegotiation Model of Tender Offer Defenses and the Delaware Supreme

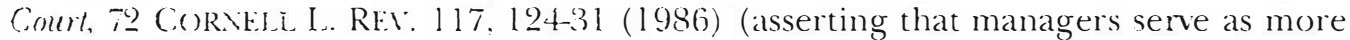
effective bargaining agents than shareholders because managers' knowledge of the company's value allowis for better offer assessment, and because they do not face the same pressure to tender in order to aroid being left out if the offer succeeds); Dale $\mathrm{A}$. Oesterle, Targrol Manasers as Negotiruting Agents for Target. Shareholders in Tender Offers: A Reply 10 the Passinity Thesi, 71 CORNELL L. REv. 53, 56-63 (1985) (arguing that shareholclers need a bargaining agent to aroid acceptance of a coercive offer); René M. Stuly, Managerial Comtrol of Loting Rights: Finaning Policies and the Market for Conporate. Control, 20 J. FIX. E(0). 25, 29-34 (1988) (modeling the desirability of managerial control of roting rights to extract a higher premium in a context where dispersed shareholders are faced with a coercive offer). These commentators, however, have not drawn the same implications from this observation as we do.

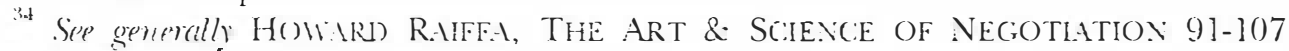
(1989) (detailing experimental findings regarding negotiative practices as they relate (6) acquisitions and mergers ).

The board could, of course, bear these costs, provide information, and advise shareholders about the proper selling strates, learing the ultimate decision to the shareholders. But in practice this option would entail the public disclosure of that information and advice, which, as discussed below; would undermine the selling strategy.

Sep. f.s.. Solicitation of Proxies, 17 C.F.R. \$ 240.1 ta (20)3) (detailing information that must be communicated tr shareholders and to the Securities Exchange Commission in a solicitation of proxy, inclucling solicitations in opposition to mergers or other exiraordinat transactions). 
contrast, a bidder has less information about the board's assessment of the company's value. ${ }^{37}$

Fourth, the board has a greater ability than dispersed shareholders to make threats and commitments that are credible. This greater ability results from the fact that the board can make investments to enhance its credibility, has a stable composition, can engage in coordinated action, can maintain secrecy about its strategy, and has the ability not to disclose its reservation price. Among other things, the board may make reputational commitments not to accept low premium offers," or may develop over-optimism (which make credible statements that the board believes that low premium offers, in fact, fall short of the company's true stand-alone value), "3!' or may even act irrationally. ${ }^{40}$ Moreover, as discussed below, the very presence of private control benefits can serve to make a commitment not to sell at a low premium credible. A dispersed and fluid group of shareholders, by contrast, lacks an effective ability to make these threats and commitments.

Importantly, Jacksonian arguments for why a board's superior ability to assess company value does not justify board veto do not apply, at least not with the same force, to the board's superior ability to develop and implement a selling strategy. First, Jacksonians argue that managers' personal interest in maintaining control makes it undesirable to entrench board power. ${ }^{+1}$ But some conflicts of interest

:37 See RuFfs, supra note 34, at $46-47$ (noting desirability of misleading the other side about one's reservation price); see also Charles B. CRAvER, EFfectTrE Lecial. Negothation AND SeTtLf.MeNT 171-72 (2nd ed. 1993) (noting that parties with a higher aspiration level achieve better results in bargaining).

See, e.g., Thomas C. Schelling, The Strategy of Confli:r 29-31, 35-43 (1980) (discussing the bargaining technique of pledging one's reputation on a public offer to create commitment-a limitation on the bargaining latitude of the agent); Davicl $M$. Kreps \& Robert B. Wilson, Repulation and Imperfect Information, 27 J. ECON. THE.ORI 253, 254 (1982) (asserting that the reputation of a bargaining agent can dissuade an opponent from actions detrimental to the agent's firm).

39. See Smith v. Van Gorkom, 488 A.2d 858, 876 (Del. 1985) (noting testimony by several executives that "as a general rule, most chief executives think that the market undervalues their companies' stock"); Ronald J. Gilson, Lipton and Rowe's Apologia for Delazure: A Short Reply, 27 DF.L. J. CORP. L. 37, 42 (20)(2) (suggesting that managers may in good faith believe that the company's outlook is positive).

" Chester L. Karrass, The Negotiating Game 71-72 (1970) (explaining the power of irrationality to achieve positive results in negotiation "if the negotiator can 1) be sure that his opponent understands what he can gain by reaching an agreement, and 2) can convince the opponent that he is emotionally committed to the reasonableness of his "irrational" position").

"See, t.... Bebchuk, summa note 31, at 991-94 (explaining the ex post and ex ante agency costs associated with board veto). 
between shareholders and managers enhance the board's ability to use a selling strategy effectively. ${ }^{+2}$ In the particular context of takeovers, private control benefits make credible the threat to reject low premium offers. If managers obtain private control benefits, it is in their actual interest to block such offers. But companies can (and do) adopt devices that reduce the degree and the effectiveness of managerial resistance as the premium rises-for example, by granting managers stock options (which become more valuable as the premium increases) or by having outside directors placed on the board who are not fully beholden to management (who may overrule managers reluctant to accept a high-premium offer). ${ }^{4: 3}$ As a result, conflicts of interest may induce a board to reject low premium bids, but not bids where the premium is sufficiently high. This, however, may be exactly the selling strategy shareholders would want to pursue. Thus, the presence of some private control benefits, which provide the intellectual underpinning for the shareholder choice regime, are not merely compatible with granting the board decision-making power, but may strengthen the case for it.

Second, boards will rarely, if ever, be able to bring shareholders up to speed by disclosing information about its selling strategy. By disclosing such information to the shareholders, the information is also disclosed to the bidder. Unlike information that relates to the substantive value of the company, such strategic information will, in most cases, lose its value if it is publicly disclosed.

Third, to implement a selling strategy effectively, a board's decision-making power must be entrenched, at least to some degree. If a board's power is not entrenched, any board decision can be overridden at any time by shareholders. But this makes it more difficult for

+2 That a principal can benefit by giving power to an agent with conflicting interests is well documented in the game theory literature. See generally Chaim Fershtman, Kenneth L. Judd \& Ehud Kalai, Observable Contracts: Strategic Delegation and Cooperation, 32 INT'L. ECON. REV. 551, 551-52 (1991) (summarizing the literature documenting the strategic adrantage of employing a bargaining agent with different incentives); Michael L. Katz, Cr(tme-Playing Agents: Unobservable Contracts as Precommitments, 22) RAND J. EC(O): 307,309 (1991) (arguing that an unobservable contract between a principal and an agent has no effect on a negotiation when the existence of the contract is common knowledge); John Vickers, Delegation and the Theory of ihe Firm, 95 Ecox. J. 138, 139-4.3 (1985) (explaining how delegating power to an agent can benefit the principal).

See Marcel Kahan \& Edward B. Rock, How I I searned to Stop Worming and Lowe the Pill: Adaptize Responses to Takeover Lazu, 69 Li. CHI. L. REV. 871, 909-11 (20)()2) (describing how firms adopt devices, such as incentive compensation and independent directors, that align managers' interests with shareholders sufficiently to reduce managerial opposition tr) changes of control). 
the board to make credible threats or commitments or employ other strategic devices." Whenever a bidder is dissatisfied with the action of the board, the bidder can just go over the board's head and appeal directly to the shareholders. Entrenching board power is thus compatible with shareholders realizing their own limitations.

Finally, it may well be desirable to entrench the board's power before a bid is received. ${ }^{45}$ In this way, the board obtains the first mover advantage in making commitments. On the other hand, if the board's power is not entrenched ex ante, it is the bidder who has the first mover advantage. This permits the bidder to take steps to signal that it will not offer a high premium. A bidder could, for example, develop a reputation as a tough bargainer, finance a bid in a way that makes raising it more difficult, or make public statements about its intentions that would expose the bidder to potential securities fraud liability if it raised its bid. ${ }^{\text {thi }}$ Alternatively, the bidder could signal an intention to withdraw its bid if target shareholders were to entrench a board's power ex post (e.g., by failing to elect the bidder's slate in a proxy contest). Thus, if a board's power is not entrenched before a bid is received, it may well be too late.

As this discussion highlights, the optimal allocation of decisionmaking power depends on several empirical factors that may vary from company to company. These factors include the balance between the significance of the board's informational advantages and the importance of selling strategies, on one hand, with the various benefits from constraining agency costs on the other. Second order factors include the ability to obtain the benefits of the board's advantages without board veto (e.g., by having the board disclose its information directly or by having the board institute an auction) and the ability to constrain agency costs while still entrenching board power (e.g., as we have argued elsewhere, through the use of independent

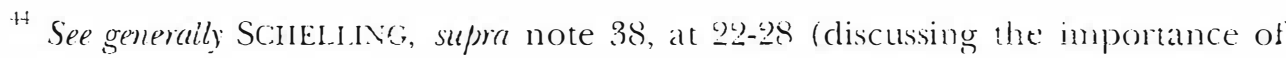
commitment in bargaining).

ti One problem with the mandatory process rule enabling shareholders to opt for a federal shareholder choice regime, see BC\&S, supra text accompanying note 6 , or a mandatory rule giving shareholders the ability to anend the corporate charter. see William W. Bratton \& Joseph A. MCCahert, Regrulatory Comprtition, Resulntong Capture, and Corporate Self-Regulation, 73 N.C. L. RE.V. $1861.192(3)(1995)$, is that these teforms would destroy such commitments and, if truly mandatory, make it impossible to make such commitments.

4i) See Marcel Kahan, Goumes, Lies, and Securities Fraud, 67 N.Y.L. L. REV. T.5(), 768-75 (1992) (describing potential liability for negotiation statements); see also (.RIVER, suprel note 37, at 246-47 (providing examples of how the use of public statements helped parties improve their negotiation positions). 
directors and executive stock options)." For that reason, different companies may make different choices, and many companies may pursue an intermediate choice and entrench a board's power to some limited extent.

Current Delaware law permits a range of options from pure Jacksonian shareholder choice to unconstrained Hamiltonian board veto. A firm can adopt shareholder choice by giving shareholders the right to remove at will a board that fails to heed shareholder wishes; it can adopt a pure board veto paradigm by means of dual class stock or a deadhand poison pill placed into the charter; or it can adopt any number of intermediate structures, including annually elected (but nonremovable) boards and classified boards. As measured by the number of months before an unsolicited bid is put to a decision by the shareholders, the options range from about one month (as dictated by federal securities law) to infinity. As we discuss in more detail below, most companies currently have governance structures that permit the board to delay a bid for either three to six months or fifteen to eighteen months. At its core, our argument in this Article is that a variety of choices of governance structures are plausible, and that shareholders' choice of a particular structure should be respected.

\section{The Analytical Perspective}

For most of this Article, we examine how different decisionmaking paradigms may affect the value of the corporation, as opposed to social wealth more broadly defined. We adopt this analytical perspective for several reasons. First of all, the focus of most of the scholarship on takeovers and takeover defenses relates to their effects on target shareholders. Second, Delaware corporate law takes the firm as the fundamental unit of analysis and constructs and enforces fiduciary duties toward the shareholders of a given firm. Thus, to the extent that several commentators (ourselves included) address their policy arguments to Delaware courts and legislators, these arguments are correctly premised on determining the set of legal rules that enhance the value of a firm, not that maximize the value of a diversified portfolio or some other measure of social wealth. Third, a full analysis of how the corporate law rules of a firm affect constituents other than its shareholders is extraordinarily complex.

ti Kahan \& Rock. suprom note 43 , at $89(-999$. 
We nevertheless want to address, if only briefly, the argument that corporate law rules should make it difficult for a company to pursue its optimal selling strategy since a superior selling strategy merely results in a wealth transfer from acquirers to targets and, therefore, does not increase social wealth. The reason we need not dwell on this point is that it has largely been addressed in the takeover debate in the 1980s. At that time, proponents of the so-called "passivity thesis" argued that all defensive devices designed to raise a bid-including the solicitation of competing bids-are undesirable because they entail costs, and any gains from a higher bid represent only private, not social, gains." Opponents of managerial passivity, which included many Jacksonian advocates of shareholder choice, replied that higher gains to targets may be socially desirable ex ante because they create incentives to invest in future target companies and for targets to search out acquirers. ${ }^{50}$ More generally, they pointed out that dispersed shareholders of a public company should have the same ability to refuse an offer as a sole owner does." And a sole owner, after all, is free to bargain to maximize her surplus even though such bargaining only results in a wealth transfer (ex post).

\section{IMPLEMENTINGa CONSTITUTIONAL REGine}

In this Part, we discuss how a desired gorernance regime can be implemented under Delaware law. In implementing such a regime, one must address two related problems: how to make a commitment stick, and whether and how to permit modifications of the commitment as time goes by. This is a problem of balancing the commitment function of the governance structure with the need to respond flexibly to unanticipated developments. That is, it is first and foremost an

is See, e.g., Easterbrook \& Fischel, supra note 24, at 1194-1204 (proposing a theory such that "shareholders would want management to be passive in the face of a tender offer").

See id. at 1175-80) (arguing that "resistance that ultimately elicits a higher bid is socially wasteful").

"See, e.g., Lucian A. Bebchuk, The Case for Facilitating Competing Tender Offers: A Reply and Extension, 35 STAX. L. REV. 23, 38-39, t2-45 (1982) (suggesting that "impeding competing bids would curtail the incentives to prospective sellers' search" and that "facilitating competing bids ... moves us closer to the optimal investment levels in any given company"); Haddock et al., sufma note 28 , at 7()6-12 (describing "[w] ealth creation through takeovers").

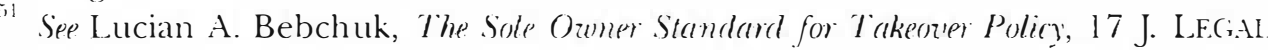
SrLD. 197. 198 (1988) (arguing that "the dispersed shareholders of a target should be able to follow the same course of action that a sole owner would"). 
exercise in constitutional design. Problems of this nature commonly emerge when the desirability of commitment and the desirability of flexibility clash, whether, as here, in the context of public corporations or in the context of state constitutions, international treaties, close corporations, joint ventures, or marriage.

\section{A. Corporate Constitutionalism}

Corporate constitutionalism raises fewer theoretical difficulties than political constitutionalism. In the corporate context, as opposed to the political context, the justification of the legitimacy of the constitutional document can more convincingly rest on a straightforward contractarian argument because consent is actual not constructive. Investors need not buy shares of a company in an IPO or secondary market if they do not like the charter. ${ }^{5-2}$ Likewise, claims of constructive consent to midstream developments based on the possibility of exit are more convincing in the corporate context than in the political context because dissatisfied shareholders have a more realistic exit option than dissatisfied citizens do: individually, they can sell their shares, and collectively, such selling can exert pressure for change by depressing the share price. As a result, the possibility of exit imposes more significant constraints on managers and controlling shareholders than on governments.

But corporate constitutions share a key feature with both older and newer political constitutions: they are instruments for making commitments that are designed to outlive the framers and their generation. Stephen Holmes makes the point nicely:

In this regard, the corporate constitution is much more similar to the older constitutions like Magna Carta, which were understood as contracts between the sovereign and different estates.

53: There is rich literature on constitutional frameworks as precommitment devices. See, e.g., Jon Elster, Consequenres of Constitutional Choice: Reflections on Tocquezille,

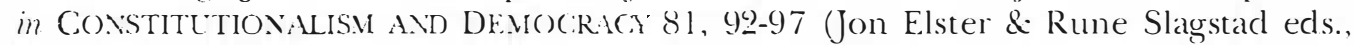
1988) (analyzing precommitment strategies given Tocqueville's view that democracy is not a stable form of government that can plan for future events or proceed systemati-

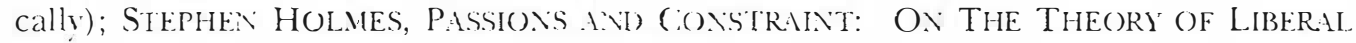
DF.rock ICY 138-62 (Univ. of Chicago Press 1995) (describing rarious political theorists views on precommitment and democracy); Samuel Freeman, Constitutional Democracy and the Legitimacy of Judicial Retipan, 9) LAW' \& PHII.. 327, 353 (1990) (noting that "judicial review is a kind of rational and shared precommitment among free and equal sovereign citizens at the level of constitutional choice"). For a book-length exploration of the incentive effects of constitutional commitments, see generally ROBBRT D. (OOTFR, THF STRATEGIC CONSTTILTION (2)(0)(0). 
A liberal constitutional framework is a classic solution to a collective action problem. People may soluntarily relinquish their ability to choose (in some matters) in order to accomplish their will (in other matters). Collective self-binding can therefore be an instrument of collective selfrule. Rules restricting arailable options can enable individuals and communities to achieve more of their specific aims than they could if they were all left entirely unconstrained. Such is the democratic function of constitutional restraints.

\section{B. Constitutional Design in Delatuare}

In understanding the Delaware corporate constitutional framework, one needs to look both to the sorts of corporate constitutional provisions permitted in Delaware and to the manner in which courts interpret constitutional terms when disputes arise. As we will show, Delaware provides a substantial degree of flexibility to participants in the design of a constitutional governance structure and generally enforces those governance arrangements literally.

\section{Topics of Entrenchment:}

What Matters May Be Entrenched?

Before turning to the "how" of entrenchment, it is worthwhile to focus on what terms can be entrenched. Here, Delaware provicles great latitude. It permits the inclusion of:

[a] ny provision for the management of the business and for the conduct of the affairs of the corporation, and any provision creating, defining,

it Holmes, supra note 53 , at 173 . There is another. more subtle war in which corporate constitutionalism is less problematic than political constitutionalism. In the political context, precommitting to delegate certain decisions to a particular decisionmaker or gorernance structure, as opposed to precommitting to a particular cousal mechanism, may conflict with a proper understanding of democratic decision making. For an acute articulation of this view, see Jeremy Waldron, Precommitment and Disagrep-

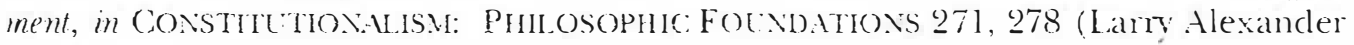
ecl., 1998):

That is, the arl of precommitment may be autonomous, but its operation may be something less than a consummation of the agent sautonomy inasmuch as it is subject to the judgment of another. In other words, it would not be a form of precommitment that enabled one to rebut an objection based on the importance of $A$ 's hanging on to his autonomy or. in the case of constitutional constraints, an objection on democratic grounds.

By contrast, in the corporate context, the parallel to clemocratic decisionmaking. namely, shareholder action, is largeiy instrumentally viewed as a means of maximizing firm value. If clelegation maximizes firm value (e.g., in the creation of a board of directors or the clelegation to the board of the sate clecision). it is no argument against that delegation that it infringes on shareholder sovereignty. 
limiting and regulating the powers of the corporation, the directors, and the stockholders. or any class of the stockholders . . if such provisions are not contrary to the laws of this State."

This general authorization, combined with more specific statutory provisions, permits tailoring across the relevant dimensions of governance: board structure and shareholder voting rights inter se.

\section{a. Board structure}

The default setting for Delaware corporations provides for management by a board of directors whose members are elected annually for one-year terms. However, Delaware law permits companies to vary these default rules in a number of ways. First, the board can be "classified" into up to three classes, thereby creating the standard "staggered" board with one-half or one-third of the directors elected each year." Second, holders of any class of stock may be given the right to elect directors with terms and voting powers that may differ from those of other directors." Third, one can place director qualification requirements, board quorum requirements, and board voting rules into the charter, or even completely opt out of the board-centered model of governance.

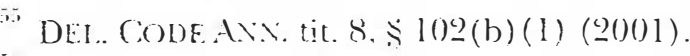

Id. $\$ 14 !(\mathrm{d})$.

Id. This statutury provision. adried in 1974 , was meant to clarify certain charter provisions defining the roting rights of preferred stockholders. Insituform of $\mathrm{N}$. Am., Inc. 1 . Chandler, 53t A.29 257, 265 (Del. Ch. 1987). Preferred stockholders commonly have contingent rights to appoint directors that mature only if the firm fails to pay certain dividends to the preferred stockholders. In a firm with a three-class classified board, if those conditions come to pass, are the preferred stockholders' rights alid: The argument against validity was that Delaware law permitted a maximum of three classes of directors. and the election of directois by the preferred stockholders would constitute an illegal fourth class. The new language was added to $\$ 141$ (d) to remore any doubt. Insitiform, $53+$ A.2d at 265 (quoting ARSHT \& BLACK, ANALYSIS OF THE 1974 AVINIMMETS IO TIE DELAWARE GENERAL CORPORATION LAW 375, 377 (Prentice Hall Corp. Serv. 1974). Interestingly, for our purposes, this provision opens up the possibility for substantial additional tailoring of governance and entrenchment going well beyond that created by a standard three-class board. For example, one can establish a term of office longer than the three-year maximum provided by the standard classified board example by tying the election of directors to a particular class of stock.

$\leqslant 1+!(b)$

$\because$ Sep $\$ 1+1$ (a) ("The business and affairs of every corporation organized under this chapter shall be managed by or under the direction of a board of directors, except as men be otheraise prosuded in this chapter or in its remtificale of incorporation." (emphasis addedi). 
Adoption of particular board structures also has implications for the permitted grounds for removal of directors. If the board is not staggered, shareholders can remove directors with or without cause. (in $^{\prime}$ But when the board is staggered, shareholders may remove directors only for cause unless the charter provides otherwise. ${ }^{61}$

\section{b. Shareholder rights inter se}

Delaware law also allows the tailoring and entrenchment of provisions governing shareholder relations inter se. Thus, one can deviate from the one-share, one-vote default setting by issuing supervoting shares or shares with no voting rights. One can provide for cumulative voting, which can assure board representation to a minority of shareholders, or give special rights to shares of a particular class. Again, these provisions implicate shareholders' ability to remove directors. When a firm has cumulative voting, a director can be removed without cause only if the votes cast against removal would not be sufficient to elect such director if cumulatively voted in her favor. ${ }^{1.3}$ When directors are elected by a particular class or series of stock, they can be removed without cause only by those same stockholders unless the charter provides otherwise. ${ }^{\text {lit }}$ Finally, one can adopt structures that tend to preserve a particular allocation of voting rights, such as, adopting charter provisions providing for "preemptive right[s]" to subscribe to additional issues of stock.

\section{c. Providing for changes over time}

Delaware's flexibility even extends to permitting future changes, with charter provisions springing into existence or "sunsetting." Thus, one can provide for "initial directors" to serve for an "initial period;" for different classes of stock to convert into a single class at a particular date $;{ }^{67}$ for a classified board as of a certain date ${ }^{6 i x}$ or one that ceases

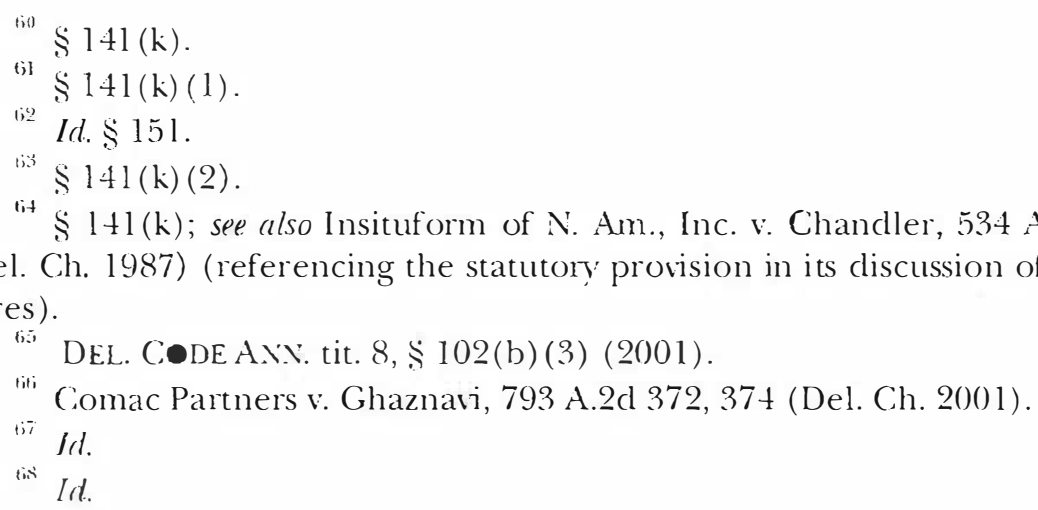


after a certain date; ${ }^{(i)}$ or for the corporation itself to terminate at some particular time and enter into liquidation. ${ }^{70}$

\section{Modes of Entrenchment}

As the political theory literature on constitutions points out, provisions can be entrenched through both formal and informal means. In Delaware, different degrees of entrenchment can be achieved through two formal mechanisms: the choice of instrument containing the term and the voting requirement to change the instrument. To modify a charter term, Delaware law requires both a recommendation of the board of directors and a shareholder vote. ${ }^{\text {I }}$ Bylaw terms can be modified either by the shareholders or by the board (or, in some companies, only by shareholders). ${ }^{72}$ Thus, placing a term in the charter results in greater entrenchment than placing it in the bylaws. ${ }^{73} \mathrm{~A}$ term can be further entrenched by requiring a supermajority vote of either shareholders or directors to change it. ${ }^{\text {it }}$ Delaware law also permits "contingent" supermajority provisions, such as a supermajority to approve a merger with any person who has acquired a defined percent of the shares prior to the merger, but not for other mergers."

Staggered board provisions, one of the most significant devices used to entrench board power, can be placed in the charter or the bylaws, but any bylaw establishing a staggered board midstream requires shareholder approval-even if the board is, in other respects, empowered to amend the bylaws unilaterally. ${ }^{76}$ For staggered boards, therefore, the difference in placement mostly affects the degree of

See, e.g., Harrah's Entm't, Inc. v. JCC. Holding Co., 802 A.2d 294, 296 (Del. Ch. 2002) (noting that a classified board structure was in place for a three-year period).

DEL. CODE ANi. tit. 8, \$102(b) (5) (20)1).

"Id. $\$ 242(\mathrm{~b})$.

Id. $\$ 109(\mathrm{a})$.

Any provision that may be contained in the bylaws may be included in the charter. Id. \$1()2(b)(l). But the reverse is not true, and many important constitutional arrangements must be contained in the charter. Id. $\$ 141(\mathrm{a})$.

it $\$ 102(b)(4)$.

5ee. e.g., Seibert v. Gulton Indus., No. 5631, 1979 WL. 2710), at*1 (Del. Ch. June 21, 1979), aff'c, 414 A.2d 822 (Del. 198()) (upholding a provision requiring an eighty per cent supermajority to approve a merger with an "entity owning 5 per cent or more of the corporation's outstanding voting stock"); see also Berlinv. Emerald Partners, 552 A.2d 482, 484-85 (Del. 1988) (discussing what triggers a supermajority vote and the quorum requirement associated with that vote).

${ }^{i t}$ DEL. CODE ANN tit. 8, \$14l(d) (2001) (providing that a board may be classified "by the certificate of incorporation or by an initial bylaw, or by a bylaw adopted by a vote of the stockholders"). 
entrenchment (rather than the ease of adoption). If the provision is placed in the charter, it can be removed only with the bilateral approval of the board and the shareholders. "If the provision is in a bylaw, the shareholders can subsequently change it by a shareholderadopted bylaw regardless of board opposition.

There are also mechanisms that provide for a degree of informal entrenchment. Thus, for example, the various and sundry provisions that make it more or less difficult for a majority of shareholders to effect change can all be understood as providing a degree of entrenchment. These provisions include governance rules that require advance notice of shareholder proposals, provisions eliminating shareholders' ability to act by consent, and adaptive devices, such as shareholder and board composition and the relative independence of the board."

There are several lessons to be drawn from this brief discussion of the dimensions of choice in the design of a corporate constitution. First, the degree of flexibility in devising a constitutional governance structure is high. Second, whatever terms are chosen, Delaware offers both flexibility with respect to the degree of entrenchment of those terms and permits varying degrees of entrenchment for different terms. Third, important constitutional choices made under Delaware law are unrelated to control contests.

\section{Entrenching Board Power}

With this brief review of the statutory stricture, we now reach the question presented to the corporate planner who wants to entrench board power over acquisitions: How to do so: The short answer given by the preceding discussion is that Delaware permits a dizzying variety of options and variations resulting in varying degrees of entrenchment.

Among public companies, several options are commonly employed. First, offering the highest level of entrenchment, a nontrivial percentage of firms enshrine control in a group of shareholders by granting them supervoting rights. Such a structure can enable shareholders who hold a minority (economic) stake in the company to

Id. S $\$$. 242 .

Id. Staggered board provisions are in fact found both in the charter and in the bylaws. Telephone Conversation with Michael Klausner, Professor of Business and Law, Stanford Law School (Aug. 29, 2()()1).

"See Kahan \& Rock, supra note 4.3, at $896-49$ (describing the arljustment by "market participants ... to Delaware takerser law through [such] adaptive devices"). 
maintain control indefinitely. Second, a staggered board with a threeyear term gives a determined board somewhat more than a year of breathing space to fend off a hostile bidder. Third, nonstaggered boards can be protected against midterm removal by denying shareholders the right to act by written consent or to call a special meeting. Though the members of such boards can, in theory, still be removed without cause, shareholders lack the effective opportunity to exercise this right. Finally, offering minimal entrenchment, a significant minority of firms enable shareholders to remove the board at any time midterm and with minimal delay by permitting board members to be removed without cause and by giving shareholders the power either to act by written consent or to call a special meeting. The large majority of firms, when they go public, opt for one of the two intermediate constitutional structures, which provide some, but less than complete, entrenchment."

\section{Corporate Constitutional Interpretation}

Suppose a firm has adopted some particular governance structure. When this governance structure is challenged, how do courts resolve the challenge? This is a question of "corporate constitutional interpretation."

The key to understanding how Delaware courts in terpret corporate constitutional documents is to take seriously the oft-repeated statement that they view the charter as a contract among the shareholders:

Corporate charters and by-laws are contracts among the shareholders of a corporation and the general rules of contract interpretation are held to apply. In the interpretation of charter and bv-law provisions, "[c] ourts must give effect to the intent of the parties as revealed by the language of the certificate and the circumstances survounding its creation and adoption."

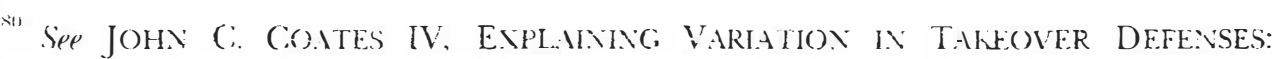

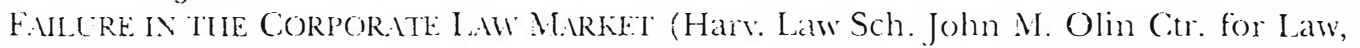
Econ., \& Bus., Discussion Paper No. 297, 2(0)(0)), available af http:/ /wwivlaw hanarcl. edu/programs/olin_center/ (providing data on clefenses by top law firms at the IPO stage and explaining the import of various defenses).

it Centaur Partiners, IV 1. Nat'l Intergroup, Inc. 582 A.2. (923, 928 (Del. 199()) (quoting Waggoner v. Laster, 581 A.2d 1127 , 113-4 (Del. 199()) (citations omitted)); see aiso Berlin v. Emerald Partners, 552) A.2d 482, 488 (Del. 1989) ("In examining the provisions of a certificate of incorporation, courts apply the rules of contract interpretation [... and ] the best evidence of the intention of the parties is often found in the express language of a writren contract." (citations omitted)); Frankino v. (Gleason, No. 
From this contractualist perspective, default rules assume substantial importance. Under Delaware law, when shareholder approval is required, a majority of shares present will generally control. When a supermajority provision appears in the charter, it will be enforced and, under an express statutory provision, cannot itself be modified by a lower majority. ${ }^{.3}$ But other departures from simple majority rule require a clear statement and will be narrowly interpreted." For example, in Frankino v. Gleason, the board, faced with a challenge from a disaffected majority stockholder, adopted a bylaw purporting to require an eighty percent supermajority vote to amend the bylaw governing board size. ${ }^{i 36}$ In his opinion, Chancellor Chandler avoided the hard and unsettled question ${ }^{x \bar{y}}$ of whether a board can validly adopt a supermajority bylaw. Instead, he held that, because the supermajority bylaw did not explicitly require a supermajority to be amended itself, a

17,399, 1999 Del. Ch. LEXIS 219, at *12-1+ (Del. Ch. 1999) (utilizing contract interpretation principles to assess the validity of a bylaw provision in a company"s certificate of incorporation), affed sub nom. McNamara r: Frankino, Titt A.2d 988 (Del. 1999); Morris v. Am. Pub. [itils. Co., 122 A. 696, 7()1 (Del. (:h. 1923) (noting that the terms of the contract between shareholders are determined by "the appropriate provisions of the certificate of incorporation and the law of the state"); R(ODMAN WARD, JR., EDWARD

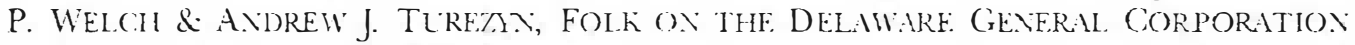
L.AW $\$ 102.16$ (4th ect. 1999) (stating that certificates of incorporation are to be construed as contracts).

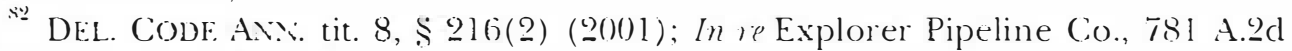
$7(05,714$ (Del. (h. 2001).

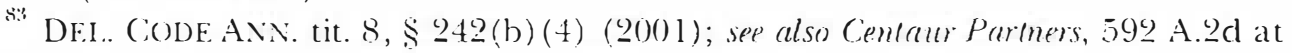
928-29 (upholding a supermajority requirement to amend a supermajority charter prevision in accordance with the "intention of the stockholders who adopted these provisions"); Frankino, 1999 Del. Ch. LEXIS 219, at*16 (noting that a supermajority" provision in a charter cannot be amended by a "bare majority rote"); Sellers r. Joseph Bancroft \& Sons (o., 2 A.2d 108, 113 (Del. Ch. 1938) (rejecting an amendment to a supermajority provision passed by only a bare majority). No equivalent statutory provision applies to supermajority requirements relating to brlaw provisions.

s.t See Standard Power \& Light Corp. v. Reid Inv. Assoc., Inc., 51 A.2d 572, 576 (Del. 1947) ("If [simple majority] rule is not to be obsenved, then the charter provision must not be couched in ambiguous language, rather the language employed must be positive, explicit, clear and readily understandable and susceptible to but one reasonable interpretation, which would indicate beyond doubt that the rule was intended to be abrogated." (citation omitted)).

1999 Del. Ch. LEXIS 19, at *12-14.

sit Id. at $* 1-\underline{2}$.

* See Chesapeake Corp. v. Shore, 771 A.2d 293. 343 n.113 (Del. Ch. 200()) (declining to eraluate the legality of a supermajority bylaw but describing such a bylaw as presenting a novel issue in Delaware corporate law). 
simple majority of shareholders could remove the supermajerity bylaw and then proceed, by simple majority, to amend the other bylaws."

A second key feature of Delaware corporate constitutional interpretation is respect for the special authority of the charter. Thus, in Quickturn Design Systems, Inc. v. Shapiro," the Delaware Supreme Court rejected a poison pill that could not be redeemed by a new board for six months after being elected (a "no hand" or "slow hand" poison pill) on the grounds that, under section 141(a), any such limitation on the board's authority would have to be placed in the certificate of incorporation."

Together, these two interpretative commitments produce a fundamental distinction within Delaware takeover jurisprudence. When directors unilaterally adopt bylaws in response to a control threat, the response will be subject to a Unocal Corp. v. Mesa Petroleum Co."1 analysis and, depending on whether they affect the voting process, possibly also a Blasius Industries \%. Atlas Corp." analysis." By contrast, when the board and the shareholders bilaterally adopt a defensive charter provision, neither Linocal nor Blasius scrutiny applies."

Frankino, 1999 Del. Ch. LEXIS 219, at *13-14. For another very interesting example of narrow interpretation of clepartures from majority rule, see In re Explorer Pipelime Co., 781 A.2d at 714-18, in which the chancery court strictly construed the terms of a supermajority provision. See also Dousman v. Kobus, 200)2 WL 1335621, at *5 (Del. Ch. June 6,2002 ) (holding that plaintiffs stated a cognizable claim that supermajority bylaw was amended by implication); Harrah's Entm't, Inc. v. JCC. Holding Co., 802 A.2d 294, 316-17 (Del. Ch. 20022) (interpreting complicated and ambiguous classified board structure bylaws to preserve ordinary shareholder's right to nominate directors).

721 A.201 1281 (Del. 1998).

Int Id. at 1291. Similarly, in Carmody v. Toll Bros., 723 A.2d 1180,1 199(-9) (Del. Ch. 1998), Chancellor Jacobs rejected a "deadhand" poison pill on the grounds that, under section $l+l(d)$, any distinction in the voting power or rights among directors must be set forth in the charter. Indeed, the fact that Delaware law permits such distinctions only by charter provision, while (jeorgia permits such distinctions in the charter or bylaws, provided the basis for distinguishing Invacare Corp. \%. Healthd yne Terhnologies, Iric., 968 F. Supp. 1578,1581 (N.D. (Ba. 1997), the Georgia case upholding a "dead hand" pill. See Carmody, 723 A.2d at 1192 n.38 (distinguishing Invacare on the grounds that the "relevant Delaware corporate statutory scheme... differs materially from that of Georgia").

See 493 A.2d 946, 955 (Del. 1985) (holding that a board's decision to adopt a defensive measure must be "reasonable in relation to the threat posed").

See 564 A.2d 651, 662 n.5 (Del. Ch. 1988) (permitting a board to interfere with shareholder franchise only under "extreme circumstances").

Chesapeake Corp. v. Shore, 771 A.2d 293, 320) (Del. Ch. 2000).

See Williams v. (Eeier, 671 A.2d 1368, 1376 (Del. 1996) (indicating that neither a Lnocrel ner a Blasius analysis applies without unilateral board action). 
Note the literalism and absence of paternalism in the Delaware approach. The statutory structure provides a wide range of options with respect to a wide range of properties. Parties can deviate, even substantially, from the statutory defaults, although they may need to make their choices clear. This largely contractual approach, as we will see, has implications for the treatment of interactions among provisions as well as the treatment of provisions over time.

\section{Is There a Single Best Paradigm? The Empirical Evidence}

In this Part, we turn to the empirical evidence regarding the effect of governance structures designed to entrench board power. We discuss the governance terms at the time of a firm's IPO, the effect of staggered boards on hostile bids, the relation between poison pills and takeover premia, legislatively imposed staggered boards, and shareholder voting on staggered boards. W'e find that the evidence is most consistent with the view that different governance structures are desirable for different companies and that intermediate levels of board power may well be superior for a majority of companies.

\section{A. Antitakeover Provisions at IPOs}

At the time of their IPO, most companies opt for a Madisonian power structure that lies between Jacksonian shareholder choice and Hamiltonian board veto. According to an empirical study by Robert Daines and Michael Klausner, about $40 \%$ of IPO companies have staggered boards." Another 20\% do not have staggered boards, but make it difficuit to remove directors between annual meetings." Only about $10 \%$ of the companies have stricter antitakeover defenses, such as dual class stock, ${ }^{1 /}$ and none restricts the ability of boards to adopt a poison pill. ${ }^{1 ; \%}$ The remaining $30 \%$ of the companies permit remoral of directors between annual meetings, thereby basically adopting a shareholder choice regime. These choices support the Madisonian

Sep Daines \& Klausner, supro note 33, at 96 tbl.2 (indicating that $44 \%$ of a sample of 310 IPOs in 1994-97 had staggered boards); see also Coates, supra note 33, at $1353.1376(34 \%$ of a sample of 162 IPOs in 199)1-92 and $66 \%$ of a sample of 162 IPOs in 1998); Laura (aasares Field \& Jonathan M. Karpoff, Takeorer Defenses of IP() Firms, 57 J. Fin. 1857,1861 tbl.II (29)(2) ) (36\% of 1019 IPOs in $3988-92)$.

"Telephone Comversation with Michael Klausner, Prof essor of Business \& Latw; Stantord Lam School (Aug. 29, 2()() l).

See Daines \& Klausner, supra note 33 , at 96 thl.2 $(6 \%$ have dual class stock out of sample of 310 IPOs in 1994-97).

lll. at 95 . 
view that different governance structures may be appropriate for dif-. ferent companies."

For a long time, it was widely believed that the governance structure at the IPO stage reflected the terms that maximize company value. ${ }^{1 ! \prime \prime}$ In the $1980 \mathrm{~s}$, mainstream academic opinion took it as a given that governance rules set at the time of an IPO were likely to be efficient and distrusted rule changes after a company had gone public ("midstream" changes)." Academic opinion started to shift in the late 1990s." There were several factors behind this shift. First, the findings that IPO charters regularly included antitakeover provisions highlighted the inconsistency of two cherished academic views: the efficiency of the IPO market and the inefficiency of antitakeover provisions. ${ }^{103}$ Second, increased stock ownership by institutional investors

Daines and Klausner try to test the validity of the bargaining hypothesis by examining whether the antitakeover clevices are correlated to the arerage number of parties making acquisition bids in a firm's history. They argue that a target needs less bargaining power when it can entice a competing bid and use the average number of bidders in a target's industry as a proxy for competition. They find that antitakeover defenses are positively correlated with the average number of bidders, which is incomsistent with their interpretation of the bargaining power theory. Howerer, as subsequently discussed, the extent of potential competition is only one of ser eral factors that determines the optimal selling strategy, and the average number of bidders in an industry is, at best, a rough proxy for the degree of competition for a specitic target. Ser" infra text accompanying notes 11 2-15 (discussing and evaluating Daines and Klausner's conclusion regarding the frequency of staggered boards in relation to the number of firms making acquisition bids).

(1w) See Daines \& Klausner, supra note 33, at 83 (noting the "widely held view[] . . that firms at the initial public offering (IPO) stage establish efficient goremance structures").

1") See, e.g., Lucian A. Bebchuk, Foreward, The bebate on Contractual Freedom in Conporate Lau, 89 CoLEM. L. REV. 1395, 1399-1 408 (1989) (arguing that initial charter terms are more likely than midstream changes to benefit shareholders); Ronald J. (rilson. Evaluating Dual Class Common Stock: The Relevance of Sulstilutes, 73 V.A. L. RFr. 8()T. 808-11 (1987) (favoring regulation of dual class common stock unless established at IPO); Gilson, supra note 6, at 829-297 (faroring limits on shareholders' ability to approve charter amendments based on the argument that shareholders are ignorant);

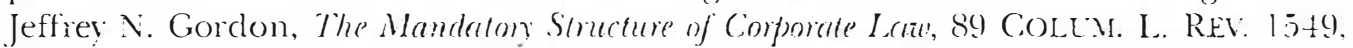
1555-62. 1579-75 (1989) (arguing that charter provisions at the IPO stage are likely (o) be "wealth-maximizing" while later amendments may" be "weal th-reducing" due to opportunism by company insiders)

"'." See Kahan \& Rock, supre note 43, at 887 n.7T (remarking on that shift). Epitomizing how much academic opinion has moved, Bernard Black and Reinier Kratikman recently remarked that the fact that staggered board provisions are included in IPO charters, rather than adopted midstream, "weakens the claim that they are sensible goremance rules." Black \& Kratkman, supra note 6, at 562 .

In: So Daines \& Klausner, summote 3.3 , at $8.3-86$ (noting this inconsistency). 
arguably improved the quality of voting decisions. ${ }^{1 / 4}$ Finally, academics noticed that, although investors regularly purchased shares of companies with antitakeover provisions at the IPO stage, ${ }^{1105}$ they of ten voted against new antitakeover provisions midstream. ${ }^{\text {Ini }}$ Thus, investors' voting decisions accord more than their buying decision with the Jacksonian view of the correct governance regime.

We are sympathetic to the notion that changes in stock ownership have improved the overall reliability of shareholder voting decisions ${ }^{10 i}$ and do not claim that the governance structures adopted at IPOs amount to conclusive proof of which regime is optimal. ${ }^{\text {ins }}$ But, unlike the Jacksonians, we continue to believe that the IPO charter terms provide substantial evidence of appropriate governance structures.

\section{B. The Incidence of Staggered Board Provisions}

In the 1990s, the percentage of IPO firms with staggered boards increased. John Coates reports that this percentage grew from $34 \%$ in 1991 and 1992 to $66 \%$ in 1998..$^{1(*)}$ Consistent with such an increase, Daines and Klausner, who examined firms going public from 1994 to 1997 , report that $43.4 \%$ of IPO firms had staggered boards. ${ }^{111}$

The increase of staggered board provisions during the 1990s is consistent with a thesis that we have developed in another article: that

"1" See Edward B. Rock, The Logic and (Uncertain) Significance of Institutional Shareholder Activism, 79 GEO. L.J. 445, 447-5l (1991) (describing examples of informed activism by institutional shareholders).

Iiv Se Daines \& Klausner, supra note 33, at 84, 110 -13 (documenting that most companies have antitakeover provisions in their charter when they go public and rarely opt out of default antitakeover provisions in the law, and remarking on earlier beliefs by commentators that firms go public in an easy-to-acquire form and that defensive provisions are added later).

lowt See Michael Klausner, Institutional Shareholders, Private Equity, and Antitakeover Protetion at the IP() Stage, 152 U. P.A. L. REV: 755, 756, 784 (2003) [hereinafter Klausner, Private Equity] (suggesting that institutional investors should oppose antitakeover provisions in IPO charters just as they oppose such provisions in shareholder votes).

"'si' See Rock, supra note 104, at $448-49$ ("As shareholdings become concentrated in fewer and more sophisticated hands, it is tempting to conclude that shareholders will finally be able to orercome [collective action problems]" and that "the institutional investor would seem to have both the incentive and the abilities to constrain management. Recent derelopments proride some encouragement for these hopes.”).

lis see Lucian A. Bebchuk, Why Firmis Adopt Antitakeoter Arrangements, 152 U. PA. L. REV. 713, 714-28 (2003) (noting that investors accept structures at the IPO stage that would be rejected later); Klausner, Privale Equity, supra note 106, at 768 -69 (noting a similar result for institutional investors).

"1t!' Coates, supra note 33, at 1353, 1376.

11". Daines \& Kausner, supro note 3.3 , at 96 tbl.?. 
companies have successfully pursued various adaptive devices-specifically, more independent boards and stock option-based compensation-to ameliorate the conflicts of interests between managers and shareholders when faced with a takeover bid. "' Given these devices, it becomes desirable for more companies to adopt governance terms through which shareholders entrench board power to a greater degree.

Among IPO firms, Daines and Klausner find that staggered boards are more common for companies that operate in an industry with a higher number of firms making acquisition bids (relative to the total number of firms operating in that industry), and interpret that finding as inconsistent with their bargaining power hypothesis. "'" They argue that the relative number of parties making bids is a proxy for potential competition among bidders and that bargaining power is more important (and staggered boards therefore should be more common) when there is less potential competition."

One problem with Daines and Klausner's interpretation is that the relative number of parties making bids is only a very rough proxy for potential competition. ${ }^{114}$ Instead, that number reflects industry takeover volume, relative to the number of firms operating in the industry. Industry takeover volume, in turn, is likely to be correlated with the probability of a synergy-producing takeover, where the division of gains between the bidder and the target shareholders is likely to be an important issue. It may therefore be desirable for target shareholders to entrench board power in order to obtain a higher share of these gains. Viewed from this perspective, the correlation between staggered board provisions and the number of parties making bids in the firm's industry is consistent with the Madisonian view that entrenching board power may be desirable because it enhances a board's ability to pursue a selling strategy.'"

11 Kahan \& Rock, supra note 43; see alse Guhan Subramanian, The Disappearing Delaware Effect, J.I. ECON. \& ORG. (forthcoming Apr. 20()t) (manuscript at 18-21. on file with authors) (discussing how stock option compensation may bring managers interests in takeover situations more in line with those of shareholders).

11". Daines \& Klausner, supra note 33, at 1(1)3-(1)4.

113. Daines \& Klausner, supra note 33, at 98 .

11 Another problem is that potential competition is only one of many factors that bear on the desirability of entrenching board power to enable boards to pursue a selling strategy effectively. See supro text accompanying note 47 (discussing several factors that determine the optimal allocation of decision-making power).

${ }^{115}$ By contrast, industry takeover volume is less likely to be correlated with disciplinary takeovers. In disciplinary takeovers, the division of gains between the bidder and the target shareholders may also be an issue. However, with respect wo such 


\section{The Effert of Staggered Boards on Hostile Bids}

In a recent empirical study of hostile acquisition offers, Lucian Bebchuk, John Coates, and Guhan Subramanian (BC\&S) find that staggered boards significantly increase the likelihood of a target remaining independent and conclude that staggered boards harm shareholders.'

The BC\&S data do not warrant this conclusion. Hostile bids are made after consensual negotiations have broken down. If staggered boards are an effective bargaining device, by making the board's re fusai to accept an offer more credible, it necessarily follows that, onc negotiations have broken down, companies with staggered boards are more likely to remain independent than those without staggered boards. The BC\&S results thus suggest that staggered boards are ef fective; but they do not suggest that they are undesirable. ${ }^{11 ;}$

To determine whether boards use their bargaining power to raise acquisition premia, one needs to examine deals where the bidder and target reached an agreement-that is, "friendly" deals-which are not included in the BC\&S sample. ${ }^{118}$ The number of friendly deals dwarfs the number of hostile bids. ${ }^{1 ! 9}$ Thus, even if staggered boards have only a minuscule effect on the target's ability to obtain a better offer in friendly deals, the net effect of such improvement is likely to out weigh the loss from hostile bids blocked by staggered boards. ${ }^{19}$

takeorers, agency costs are likely to be high and may make a commitment to boarc veto undesirable.

1"ii BC:\&:S, supra note 6 , at 891,950 .

${ }^{117}$ The BC.\&S authors also adduce evidence that the rejected hostile offer of ten i: above the independent value of the company. See BC.\&S, sufra note 6, at 926 (finding that the arerage final bid that a hostile bidder makes is $43.2 \%$ orer the pre-bid marke price). This, of course, is consistent with staggered boards being used to enable board to pursue a selling strateg: more effectively. See supro text accompanying note 111 (discussing how staggered boards have been acopted to ameliorate conflicts of in terest between managers and shareholders when presented with a hostile bid).

"1: See Mark Gordon, Takenuer Defenses Work. Is That Such a Bad Thing?, 55 ST.A.. L, RFY. 819, 822-2+ (2002) (arguing that the BC\&S study used an overly narrow data se br limiting the data to hostile transactions).

11.) See infra text accompanying notes 124-26.

With respect to hostile of fers, the BC\&S authors report that acquisition premia are five percent higher when the target has a staggered board then when it does not BC\&\&, supra note 6 , at 935-36. While the difference in premia is not statistically sig nificant, the BC\&S sample of successful hostile offers is very small (seven involving companies with staggered boards, fifteen for companies without), id. at 930) fig.3, ane their test thus lacks power. At the rery least, these data do not show that boards fail to use the bargaining power conferred on them by staggered board provisions to raise premia. 
Indeed, perhaps the most noteworthy aspect of the BC\&S study is that the number of failed hostile bids involving companies with staggered boards is so small. ${ }^{121}$ Between 1996 and 2000, the period of the BC\&S study, there were over 3,000 acquisitions, ${ }^{122}$ of which about half involved companies with staggered boards. ${ }^{1 \cdot ;}$ The BC\&S authors examined the 92 hostile bids during the period, of which 45 involved effective staggered boards. ${ }^{1 \cdot-4}$ Of these 45 bids, 11 did not result in the acquisition of the target. ${ }^{125}$ What one really wants to know-and what the BC\&S data do not tell us-is whether bargaining breakdown is more common with a staggered board than without (which one would expect), and whether the benefit to shareholders in the deals that do occur offsets any losses to shareholders in deals that do not occur.

\section{The Effect of Poison Pills on Takeover Premia}

Several studies have found that acquisition premia are significantly higher for targets with poison pills than for targets without pills. ${ }^{126}$ At first blush, these studies present a theoretical conundrum: since virtually every company can adopt a pill whenever it wants, the actual adoption of a pill does not increase management's bargaining power. ${ }^{1.2-}$ But while pills do not signify increased bargaining power, the adoption of a pill signals that management is ready to use this power to extract a higher premium (at the risk of defeating a bid). ${ }^{1-4}$ Consistent with this interpretation, surprise pills-pills that were not predicted on the basis of general company characteristics—and "morning after" pills - which are adopted close to the time of a bid-have a particularly pronounced positive impact on acquisition premia. ${ }^{129}$ Even

II $I(l$.

Sey MERCERSTAT, MER(;ERSTAT REVIEW 6 (200)1) (summariang transactions involving public companies from $199(6-200(0)$.

See BCSES, supra note 6 , at 926 tbl.2 (showing $60.9 \%$ with a staggered board).

$12+1$.

Id. at 930 fig.3.

12ti See Robert Comment \&. (;. William Schwert, Poison or Placelos? Eividence on the Deterrence and Wealih Effects of Modern Antitakeover Measures, 39) J. FI. E(.0. 3. 30) (1995) (interpreting data to show that both conditional and unconditional takeover premia are higher with a pill in place): Georgeson \& Co. Ponson PII. IMPACT St my I (Mar.

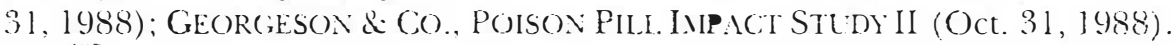

!y Se Bebchuk, supra note 31, at 10(0)-10) (noting that pill studies do not show an increase in management's bargaining power to resist hostile bick)

1." See John C. Coates IV, Takeoter Defenses in the Shadoun of the Pill: A Critique of the Scientific Ezidence. 79 TEX. I. REV. 271, 30) (20(0)) (noting that pills may serve as resistance signals).

19u' Comment d Schwert, supra note 126, at 36-37. 
though these pills also reduce the likelihood of a bid's succeeding, their net impact on target shareholders is positive. ${ }^{|\cdot n|}$ This suggests that, on average, boards resist bids (as evidenced by pill adoptions) when doing so benefits shareholders. The pill studies thus support the conclusion that shareholders can benefit by granting the board some power to resist bids.

\section{E. The Effect of Legislatively Imposed Staggered Boards}

In 1990, Massachusetts legislatively imposed staggered boards on all Massachusetts public companies, even if the charters of these companies provided for annual elections of the whole board. ${ }^{1: 3}$ Studies of this Massachusetts legislation have shown that the stock price of Massachusetts companies that did not already have staggered boards declined. ${ }^{132}$ The result of these studies is consistent with our argument that shareholder choice represents a plausible governance structure and that staggered boards are not universally desirable. Forcing staggered boards onto companies that did not opt to include staggered board provisions in their charter should thus be expected to reduce company value.

\section{F. Shareholder Votes on Staggered Boards}

Votes on staggered board proposals occur in two settings: when boards recommend amending the charter to establish staggered boards (when the company does not have one); and when shareholders put forward a precatory proposal recommending that the board act to repeal a staggered board (when the company has one).

Since the late 1980s, the number of board proposals to establish staggered boards has substantially declined..$^{133}$ This decline is due, at least in part, to managerial fear that shareholders will not vote in favor

1.31) Id. at 31 tbl. 4.36 .

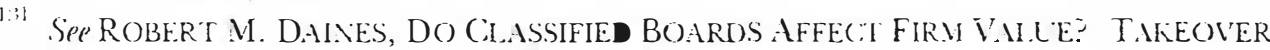
DEFENSES AFTER THE POISON PILL 1 1-12 (working paper) (discussing the erolution of Mass. House Bill 5556 and its effect on Massachusetts firms).

13: Id. at $16-17$ tbl.2.

1.: Klausner, Private Equity, supra note 106, at 759 tb1.2. Lntil the $198($ )s, when a significant number of proposals to establish staggered boards were made, such proposals had no significant effect on share price. See Coates, supra note 128, at $317-25$ (summaring results of erent studies). 
of such proposals. ${ }^{1: 34}$ In contrast, precatory proposals seeking to repeal staggered boards have increased both in number and in the shareholder support they receive. ${ }^{13}$ In 2000, such proposals on average garnered, for the first time, the support of more than fifty percent of the votes cast. ${ }^{1.16}$ Some commentators have interpreted this evidence to show that staggered board provisions are undesirable and only survive because the board refuses to heed shareholder wishes. ${ }^{137}$

The shareholder voting record stands in apparent contrast to the significant percentage of IPO charters that provide for staggered boards. But both the voting record and, obviously, the IPO evidence are consistent with the view that staggered boards are desirable for some, but not all, companies.

Take first the evidence regarding shareholder resolutions to remove staggered boards. According to the Investor Responsibility Research Center, which collects data on shareholder proposals for two thousand companies, on arerage only about fifty proposals to remove staggered boards are made per year. ${ }^{13:}$ Several of these proposals are not supported by holders of a majority of shares voting, and only a few are supported by holders of a majority of outstanding shares (the level of shareholder support required to change the charter).

Si: Se, e.g., Coates, supra note 128 , at 325 (discussing how the difficulty of obtaining shareholder approval of staggered board provisions has led managers to stop proposing such charter amendments).

1:3 $\mathrm{B}(\mathrm{\&}: \mathrm{S}$, supra note 6 , at 9(0). By contrast, there have been only a few shareholder proposals to make directors more easily removable between annual meetings, and the number of shareholder proposals directed against poison pills have declined. Ser Kahan \& Rock, supra note 43 , at 886 n.74 ("[S] hareholders have made only minimal efforts to get companies to adopt charter provisions-allowing shareholders to act by written consent or to call special shareholder meetings and making directors removable without cause-that would permit the replacement of directors between annual meetings ...."); see also Stuart L. Gillian \& Laura T. Starks, Corporate Gournance Proposals and Shaveholder Actizism: The Role of Institutional Investors, 57 J. FIN. ECO: 275 , $286(20()())$ (showing that the number of shareholder proposals submitted to eliminate poison pills wats 52 in 1991, 32 in 1992, 29 in 1993, and 15 in 1994).

1:36 See BC\&S, supra note 6 , at 90() ("The average shareholder vote in faror of proposals to de-stagger the board increased from $16.4 \%$ in 1987 to $52.7 \%$ in $2(0)()() . ")$.

1:37 See, e.g., id. at 943-44 (suggesting that shareholders would likely' refuse to ratify staggered boards today if given the opportunity to express their views).

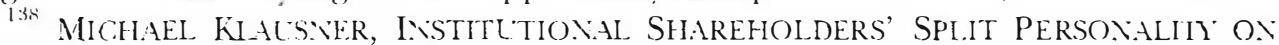

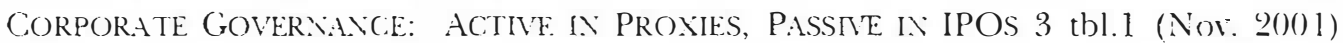
(Stanford Law \& Economics Olin Working Paper 225), azcallable al http://olin.stanforcl. edu/workingpapers/.

1:3: Georgeson Shareholder Inc., 2000) Anmual Weeting Séason Wrap-Cp: Conporate Goternance 1 1-12 fig. 14, at http://www.georgesonshareholder.com/pdf/o()WrapLp.pdf (reporting voring results for 19 proposals, of which 3 gained support by a majority of 
Moreover, one needs to be careful in interpreting shareholder rotes on precatory resolutions. Shareholders know that their votes are only advisory, and they may therefore pay little attention to the issue being roted on, or may use their votes more to send a message (of dissatisfaction with management or with the structure of the board) than to affect the substantive issue. ${ }^{1+11}$ Indeed, resolutions are often introduced at those companies where shareholder dissatisfaction is the highest." $\quad$ Thus, shareholder support for proposals introduced at such companies is likely to be higher than shareholder support would be for the same resolution were it to be introduced at an average company. Finally, because neither side campaigns heavily on precatory resolutions, the shareholder vote may only be an inaccurate predictor of how the vote would have turned out if the same resolution had been binding.

The reluctance of nonstaggered boards to propose amending the charter or bylaws to establish a staggered board, in turn, can be due to a variety of factors. For one, staggered boards are not desirable for all companies and are less likely to be desirable for those companies that have not yet established them. ${ }^{1+2}$ Second, individual shareholders have limited incentives to assess information on a roting decision, since they are aware that their votes are unlikely to affect the outcome. " Thus, shareholder votes on staggered boards may be determined by whether staggered boards are, on average, desirable for

outstanding shares, 11 by a majority of votes cast. and $1+$ by a plurality of votes cast). Vote that while several institutional investors have stated policies opposing staggered boards, see, e.g. The Vanguard Group, Proxy boting Policy, al http:/ / Www.ranguard. com/web/corpcontent/CorpAboutVanguardProxyVoting html (last visited Jan. 6, 2(1).3) ("We will generally support proposals to declassify existing boards . . and will block efforts by companies to adopt classified board structures."), to our knowledge none have made substantial efforts to get companies to repeal staggered boards. In other areals, such efforts have had significant success. See, eg., Kithan \& Rock, supra note 43, at 895 n. 11 2 (describing TIAA's successful campaign against dead-hand pills).

1:"i" Sere, e.g. Lilli A. Cordon \& John Pound, Informalion, Oumership Structure, and

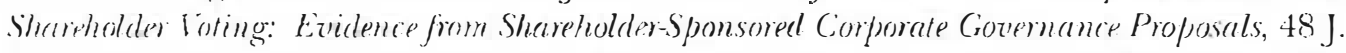
Fix. 697, 712 (1993) (finding that the worse a firm's long-term performance, the higher the vore for a shareholder proposal).

${ }^{1 * 1}$ See, p.g. Jonathan M. Karpoff et al., Corporale Covernance and Shaveholder Iniliatives: Limpirical Fididence, 42 J. FIN. ECON. 365, 365 (1996) (fincling that firms attracting governance proposals have poor prior performance); Michael P. Smith, Shareholder totivism by Institutional Investors: Fividence from CalPERS, 51 J. FIx. 2297, 232 (1996) (reporting that (alPERS selects targets for governance initiatives based on performance).

it: Sie supra Part IV.E-F.

11: Sep Lucian Arye Bebchuk \& Warcel Kahan, A Framework for Analying Legal Policy Toutards Proxy Contests, 78 C.LL. L. REv. 1071, 1080-81 (1990)) (discussing reasons why shareholders lack proper incentives to obtain information on voting decisions). 
those companies that lack them, rather than by whether they are desirable for a specific company. Third, boards may be reluctant to put forward staggered board proposals that have a significant chance of failing because failure causes embarrassment, shows a lack of confidence with management, may signal management's fear of a hostile takeover, and may result in putting the company "in play." Thus, a failure to propose establishing a staggered board may be due to uncertainty over whether the proposal will pass, rather than certainty that it will fail. Indeed, in those instances where boards propose staggered board amendments, the amendments garner significant shareholder support, often including a majority of votes from shareholders unaffiliated with management.'

\section{ENFORCING THE GOIERNANCE CHOICE}

Let us then assume that entrenching board power in general, and choosing to have a staggered board in particular, can be a reasonable shareholder choice. This then raises two fundamental and related questions. First, to what extent will the courts recognize and enforce the constitutional choice, especially when the board inadvertently failed to close some loopholes in implementing it? Second, what about surprises? What is the court's role when a provision, which has been adopted during one period, in a specific context, later turns out to have different and unexpected effects? We address these questions in turn.

\section{A. The Problem of Sloppy Implementution}

As discussed earlier, the choice of a staggered board is, in part, a choice by shareholders to entrench the board. In the standard classified board, adopting a staggered board means that it will take two elections for a dissident to elect a majority of the board.

But now consider the following situation. A corporate charter provides for a three-class classified board and authorizes a board of up

"For example, a $2(0) 1$ proposal by Rotary Power Intemational to adopt a staygered board was approved with 9,4()1,435 shares roting in faror and 63,284 against. Rotary Power Int'l FORM 10-QSB (Sept. 3(), 2i)()1), http://ritwisec.gor: Directors and officers held 2.6 million shares. Id. A similar proposal by Hauppauge Digital received $3,2(04,4(0)$ votes in faror and $422,(2) 1$ against. but failed because insufficient rotes were cast. Hauppage Digital, Inc. Form 10-Q (Dec. 31. 2(1)1), htip://mmw.sec.gor. Directors and officers held about $8(0),(0)()$ shares. Id. A proposal by Symmetricom wats defeated by 10,364,842 votes to 6,523,156 rotes. Srmmetricom, Inc. Form 10-Q (Dec. 31, 20(01), http: / /mow.sec.gor. Directors and officers held about $5(0) .(0)(0)$ shares. Id. 
to nine members. The actual size of the board and the designation the class of directors is through bylaw (and the board is authorized the charter to enact bylaws). Due to inattention, the board sets th size at five directors divided into three classes. Now along comes bidder, who proposes to contest the election of the two directors $\mathrm{l}$ for election at the next meeting, to expand the board from five nine, and to nominate four individuals to fill those four newly create seats. If the bidder succeeds, it will be able to take control of th board in one meeting, despite the presence of the classified boar Suppose the board responds by expanding the size of the board fro five to seven and electing two new directors. In such a case, even the bidder wins the two seats up for election and wins its proposal expand the board to nine members, it will still only end up with for seats. Is that board action, assuming it is in good faith, valid?

These facts closely resemble the facts of both Blasius ${ }^{1+5}$ and, th more recent, Liquid Audio, Inc. ${ }^{1+i}$ These cases present a situation which a staggered board can be circumvented by a bidder and is th not an "effective staggered board," to use Bebchuk, Coates ar Subramanian's phrase. ${ }^{14 \bar{\gamma}}$ Unintentionally in effective staggered boar raise a nice question. On the one hand, if one interprets the adoptic of the staggered board as a shareholder commitment to a governan structure that requires winning two contested elections in order gain control, then the board's actions can be justified as protectir and implementing that structure, albeit with a certain tardiness. Aft all, had the board been diligent and scrupulous in maintaining th governance structure, it would have recognized that a classified boal with five members, when the charter authorizes nine, is no classifie board at all. From this perspective, one could argue that it is bett that the board create an effective classified board at the last minute, expanding its size to seven and appointing two new members, tha perpetuate its earlier mistake.

On the other hand, if one examines only the current time perio after the bidder has made a bid, it looks like the board is distortir the outcome of the contest by interfering with shareholders' fra chise. The board's action, albeit in good faith, is for the purpose preventing the shareholders from electing particular candidates. Or might, for example, argue that the board is free to expand the boal

1.15 Blasius Indus. v. Atlas Corp. 564 A.2d 651, 651 (Del. Ch. 1988).

1.ti MM Cos. V. Liquid Audio, Inc., 813 A.2d 1118,1122 (Del. 2003).

ti BCis.S. supren note 6 , at 890 ). 
and appoint new directors fifty weeks out of the year, but during the two weeks of the election contest, it must stay its hand.

In Blasius, the Delaware Chancery Court adopted this second view. $^{1+8}$ Atlas' certificate of incorporation provided for a three-class classified board. ${ }^{\text {!! }}$ The certificate set the maximum number of directors at fifteen, with the actual size determined by bylaw; the bylaws set the size of the board at seven. ${ }^{15 n}$ The charter also did not preclude shareholders from acting by consent. ${ }^{1.51}$ In other words, the classified board was not an effective classified board because the board had fixed the number of directors too low. The bidder launched a consent solicitation to enact a bylaw to expand the size of the board to fifteen and to fill the eight new seats with its own candidates. ${ }^{152}$ If successful, this consent solicitation would have given Atlas' nominees immediate control of the board. ${ }^{13}$ To block this eventuality, the board expanded its number from seven to nine, and then appointed two new directors.

The case thus presented a classic example of a potentially effective classified board that failed because the board did not pay attention to detail. The chancery court imposed a "compelling justification" test and erjoined the board's defensive action, concluding that its purpose was to interfere with shareholders' franchise. ${ }^{1 n}$ other words, the board, having failed to implement the shareholders' govarnance choice, was precluded from doing so later when the governance choice actually would have made a difference.

In Liquid Audio, the Delaware Supreme Court adopted a similar approach, albeit on an odd factual record. ${ }^{15 i}$ Unlike Blasius, Liquid. A udio involved the actions of a board classified by bylaw rather than by charter. $^{15 i}$ Consequently it was not, in fact, an effective staggered board because it could be repealed by a shareholder-approved bylaw. Given shareholders' inherent power to adopt bylaws, ${ }^{\text {l: }}$ a bylaw staggered board is no more entrenched than an unclassified board,

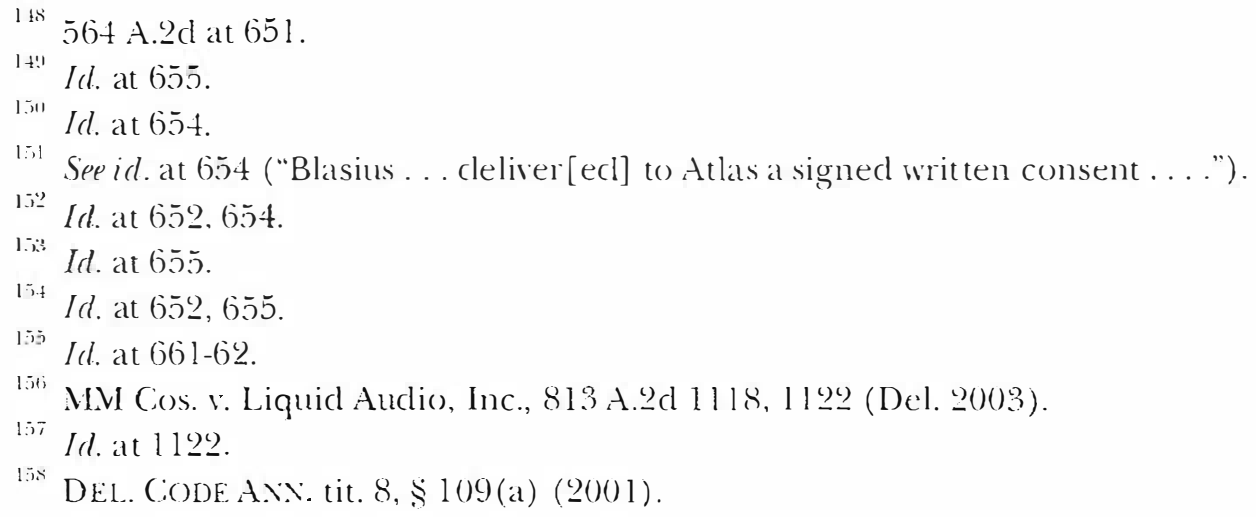


except insofar as the corporation's charter requires a supermajority to amend the bylaws (as was the case in Liquid Audio). ${ }^{15}$ The bylaw can be repealed at any time shareholders can act, which means that the shareholders can eliminate it at the next annual meeting and then replace the directors with directors willing to redeem the poison pill. While Blasius involved an effective staggered board that failed because of board inaction, Liquid Audio involved a board that by design was a less than fully effective staggered board.

In Liquid Audio, the board had five members, two of whom were up for election. ${ }^{\text {(ti) }} \mathrm{MM}$, the bidder, launched a proxy fight: it nominated two candidates to fill the upcoming vacancies; proposed a bylaw amendment to increase the size of the board by four; and nominated four candidates for those new slots. ${ }^{161}$ In response, Liquid Audio's board amended the bylaws to expand the board by two to seven. In the election that followed, MM won two seats on the board, but its bylaw proposal failed to receive the two-thirds vote required. Had it succeeded, MM would have controlled six seats of an eleven-person board, thereby giving it control of the company. When asked in a pretrial interrogatory why it had expanded the board, Liquid Audio answered that it was concerned that the potentially "acrimonious" relationship between MM's board members and Liquid Audio's incumbents would lead one or more of the incumbent directors to resign, thereby causing a board deadlock or transferring control to MM.

In giving this answer, Liquid Audio conceded that it had expanded the board in order to dilute MM's influence. ${ }^{162}$ Vice Chancellor Jacobs denied MM's motion because he found that the board's action did not make it harder for MM to obtain control: both under the initial and under the expanded size, MM would need the support of two-thirds of the shares to obtain control; in either case, support by a plurality of the shares would give MM minority representation on the board, but not control. ${ }^{163}$ The Delaware Supreme Court did not dispute these facts, but nevertheless held that the expansion of the board from five to seven was improper under Blasius:

The record reflects that the primary purpose of the Director Defendants action was to interfere with and impede the effective exercise of the stockholder franchise in a contested election for directors. . . That

\footnotetext{
Transcript at 5-6. MM Cos. v. Liquid Audio. Inc. (Vo. 19.869).

Liquid Audio, 813 A.2d at 1122.

liil Id. at 1123 .

In. at $1125-26$.

lii.i. Id. at 1121 .
} 
defensive action by the Director Defendants compromised the essential role of corporate democracy in maintaining the proper allocation of power between the shareholders and the Board, becanse that action wats taken in the context of a contested election for successor directors. Since the Director Defendants did not demonstrate a compelling justif ication for that defensive action, the bylaw amendment that expanded the size of the Liquid Audio board, and permitted the appointment of two new members on the eve of a contested election, should have been invaliclated by the Court of Chancery.

We believe that the Delaware Supreme Court was correct to apply Blasius even though the expansion of the board from five to seven did not make it harder for MM to obtain control. The chancery court analysis implicitiy viewed the incumbent directors (and the MM representatives) as homogeneous groups: if each group member alwars votes with her group, then the only important factor is the difficulty each group faces in getting a board majority. The supreme court's holding, by contrast, is based on riewing each director as an individual. If some of the incumbent directors may vote, on some issues, with the MM representatives-because they may be convinced by their arguments-then it is significant whether the MM representatives occupy two of five or two of seven seats on the board.

We think that the supreme court's holding is more in tune with the modern aspiration for the board and with the actual composition of Liquid Audio's board. As we have argued elsewhere, the number and influence of independent directors, who are unaffiliated with management, has grown significantly in the last decade. ${ }^{160}$ Both Delaware law and new federal regulations place increased emphasis on the number and power of independent directors. One premise for these laws is that independent directors are capable of exercising their own business judgment, rather than blindly following the commands of management. The directors of Liquid Audio certainly fit that picture. Of the three directors whose seats were not contested, one (Winblad) just recently had voted against a def ensive merger proposed by management.

A more interesting case would have been presented had Liquid Audio given a more neutral response to the interrogators. ${ }^{\text {in }}$ For

li.t Jit. at 1132 .

se hathan \& Rock, supra note 43, at 897 (stating that independent directers are playing a greater role in public corporations).

Liquid Audios true motiations may have been even worse than conceded. Director Winblad had opposed the merger with Alliance, as did MM. With the two new M.M directers and Hinblad comtinuing on the beard, there would hate been a :3-? 
example, suppose that Liquid Audio's sole explanation for expanding the board was that it needed additional independent directors in order to fulfill all of the duties imposed by the Sarbanes-Oxley Act of $2002{ }^{1 \hbar i}$ related SEC rules, and changes in stock exchange listing requirements.

Here we get to the purer case: a bylaw-classified board that has been poorly implemented. If one takes the bylaw/charter distinction seriously, as Delaware does, then one could argue that a classified board established by bylaw is designed only for the sake of convenience (electing only a third of the directors each year) without entrenching the board, while a board classified by charter can be understood to do both.

If this is the proper understanding of a bylaw-classified board, then, even if we set aside the problematic interrogatory answer, Liquid Audio can be understood to be a case in which the board's defensive actions went beyond the degree of entrenchment opted for in the governance structure. That is, the board's actions went beyond merely correcting sloppy implementation to an attempt to dilute the influence of the challengers. The board expanded its size by two and placed both new directors in classes that would not come up for election at the next annual meeting. ${ }^{\text {lis }}$ In doing so, it reduced the percentage of directors elected in the upcoming election from $40 \%$ to $29 \%$. Notably, had the board expanded its size by three, the percentage of directors up for election would have dropped only to $38 \%$. It thus seems that the board action was purposefully designed to minimize the percentage representation of the newly elected directors. From this perspective, the outcome in Liquid Audio would still be correct. ${ }^{\text {iti }}$

By contrast, Blasius is more troubling because it is a case in which the board's defensive actions conformed precisely to the degree of entrenchment opted for in the charter (albeit a bit tardily). To justify Blasius on this analysis, one needs an additional "better never than late" argument based on the sanctity of the election period. One

majority against the merger. With an expansion of the board to 7 . there would still be a $4-3$ majority in faror.

16i Pub. L. No. 107-204, 116 Stat. $745(20(0) 2)$.

vivis 813 . 2 d at 1124.

There is a potential complication. In Liquid Audio, the bidder did not seek to repeal the staggered board by a shareholder-adopted bylaw, but rather to evade its strictures by expanding the board and filling the racancies. Because both tactics are equally difficult to implement and vield the same effect (i.e., one needs the same level of shareholder support at the amnual meeting as does the other), we clo not view this as a significant distinction. 
needs to argue that even though the shareholders opted for a charterstaggered board, and even though the directors undermined the shareholders' commitment by failing to appoint a sufficient number of directors to make the choice effective, the directors cannot redress their mistake once the choice actually matters, that is, once a contest for control begins. ${ }^{170}$

The lesson of these cases is that the board's defensive actions must be understood in the context of the governance structure adopted by the firm. When a firm opts for an effective staggered board, as in Blasius, the courts should respect that choice and a good-faith (albeit tardy) board attempt to implement that structure is deserving of greater deference than had the firm opted for lesser entrenchment, as in Liquid Audio. When a board attempts to confer greater entrenchment than provided for in the firm's governance structure, that act should be subject to heightened scrutiny.

Prospectively, of course, the lesson of Blasius and Liquid Audio for corporate counsel is clear: make sure that enough of the permitted seats are filled to prevent an end run through board expansion. If most counsel drew this obvious lesson from the cases, then it matters little for firms with staggered boards whether Blasius and Liquid Audio were rightly decided.

\section{B. Surprises}

We now move to a second, related issue. What is the court's role when a provision that has been adopted during one period, in a specific context, later turns out to have different and unexpected effects? What about surprises?

Surprises constitute a generic problem inherent in any system in which one can make intertemporal or constitutional commitments. Ex ante, any system that permits entrenchment of provisions will predictably give rise to future complications, because provisions have unanticipated effects. In addition, staleness and rigidity are inevitable side effects of entrenchment. No one should be surprised that there

17" In the absence of title 8 , section $102(b)(7)$ of the Delaware Code, these cases would pose an additional issue. As discussed above, there is substantial evidence that board entrenchment leads to higher premia in deals that are completed. Supra text accompanving notes 126-30. When, through board negligence, a charter-based staggered board is rendered ineffective, could shareholders seek damages, arguing that the directors breached their duty of care and that, but for their negligence, the premium would have been higher? 
are surprises (although the particular surprise will likely be surprising).

The recent history of Delaware corporate law includes quite a few such surprises. Thus, for example, section 228 of the Delaware General Corporation Law (DGCL) was amended in 1969 to permit all shareholder action to be taken by written consent unless the charter provides otherwise. ${ }^{171}$ With the rise of hostile takeovers, this section became unexpectedly important because it made it easier for hostile bidders to use consents to remove recalcitrant incumbent directors between annual meetings and to elect a new board to dismantle the target's takeover defenses.

So there are surprises. Because the fact that there will be surprises is entirely predictable, parties can and presumably do factor this possibility into their decision whether to entrench provisions. Indeed, many critical governance mechanisms are not entrenched or only modestly so. And many firms do not entrench board veto but accord shareholders the power to remove the whole board, without cause, between annual meetings should the board not do their bidding in responding to a takeover bid. When, as here, the potential downside of entrenchment is obvious, the choice to entrench a provision should be at least prima facie eridence that the expected benefit of the resulting commitment outweighs the expected losses from commitments that backfire.

Furthermore, as described earlier, companies that commit to some degree of board veto do not do so irreversibly: a firm can amend its certificate of incorporation to remove a staggered board or to enable shareholders to remove directors at any time without cause. $^{173}$ Note how Delaware law permits flexibility without destroying the possibility of robust precommitment. In contrast to bylaws, neither the shareholders alone nor the board alone can change the charter-each has a veto. Consider how it works. If the classified board and the shareholders both wish to accept an offer, then a friendly deal is negotiated. If both prefer to turn down a bid, the shareholders'

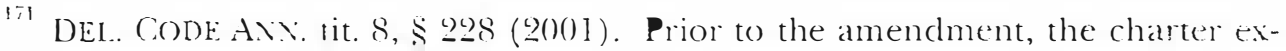
plicitly had to authorize action by written consent.

1i: For example, the presence or absence of a controlling shareholder; the selection and composition of the board; the relationship between the board and the CEO, including the eraluation and replacement of the C.EO; the selection of a new C.F.O: the relationship between the CEO and the other executive employees.

The possibility of such amendments is not purely theoretical. For example. Michaels Stores eliminated its staggered board in 2(0)1. Michaels Stores Proxy Statement \& (Nay 6. 2(0)3), http:/ / wrw.sec.gor. 
precommitment is not triggered. If, ex post, shareholders prefer to accept the bid but the board, for whatever reason (whether because the board is pro-shareholder or because it hopes to maintain control) opposes it, the precommitment to board power holds because shareholders cannot amend the charter without a board recommendation. $^{1 i t}$ Bidders, then, will have no choice but to negotiate with the board if they wish to aroid the one-year-plus delay.

Beyond such measures for limiting or modifying commitments, should shareholders want judges to intervene on a case-by-case basis to bail them out of commitments that have backfired? Recall the underlying problem: a precommitment is only as strong as the obstacles to subsequent reversal. Odysseus's precommitment strategy that allowed him to experience the Sirens' song required that he prevent himself from renegotiating terms ex post. ${ }^{1-i j}$ It was not enough simply to have his sailors tie him to the mast; he also needed them to stop up their ears with wax both to protect them from the Sirens' call and so that they could not hear and obey his countermanding order. ${ }^{17 \tau}$ Thus, if there is to be judicial intervention, it must be highly selective: otherwise, the attempt to rescue shareholders ex post will destroy the value of the commitment ex ante.

The desirability of judicial bailouts turns on whether courts can distinguish between commitments that work as intended and commitments that have backfired." One approach is that of Schnell $v$.

${ }^{17+}$ And vice versa: if the board desires to sell, but shareholders are opposed, they can vote clown a merger.

is) And note, further, how the veto power allows the same charter to be used to make credible commitments to other groups such as preferred stockholders. By putting the terms of preferred stock into the charter, changing those terms requires a class-wide vote and thui creates a specific bilateral veto.

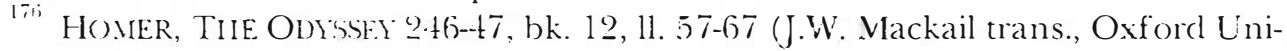
versity Press 1932).

iti Id.

${ }^{17 x}$ Not all legal inteiventions constitute commitment bailouts. Sometimes, a new law or doctrine is needed to clarify an ambiguity or to address a novel issue. At other times, the law may be modified to expand the arailable choices. The adoption of title 8 , section 102(b)( 7 ) of the Delaware Cole, which permits charter amendments to opt out of monetary liability for breaches of the cluty of care, falls in the latter category. DEL. CODE AN tit. S. S $102(b)(7)$ (20)(01). Even choice-enhancing legal interventions, however, have a secondary impact on commitments. Arguably, Delaware law as it existed before the adoption of section $102(\mathrm{~b})(7)$ entrenched a commitment not to opt out of monetary liability for breaches of fiduciary duty. Nore likely, however, such law reflected a wide understanding that no monetary liability would be imposed for breaches of the cluty of care-an understanding that was shaken by Simith r. Van (Gomkm. 488 A.2d 858 (Del. 1985). 
Chris-Craft Industries, Inc., ${ }^{179}$ namely, to use fiduciary duty law to carve out an opportunity for judicial action when the board is acting purely for bad reasons such as entrenchment. ${ }^{180}$ Thus, in Schnell, the court held that the directors could not advance the date of the stockholders meeting, even though permitted by the bylaws to do so, when they were doing so for the purpose of obstructing the legitimate efforts of dissident shareholders to conduct a proxy contest.

For courts to go even further in rewriting precommitments, they would have to be able to distinguish between real examples of precommitment misfiring and examples of precommitment binding as intended. In both cases, shareholders will knock at the courthouse door asking to be let out of their bargains. The external manifestations will be similar. If the court's error rate is high, allowing the courts to try to distinguish cases in which bailouts are warranted will tend to undermine the very possibility of precommitment.

Is the poison pill the sort of unhappy surprise that has caused a commitment, represented by a staggered board provision, to backfire and that might justify a judicial bailout? Several commentators have suggested that in the pre-pill days when most staggered boards were adopted, they were a rather ineffective antitakeover device. ${ }^{1 * 2}$ Raiders would just consummate the tender offer, and a board, faced with inevitable ultimate ouster, would cave in and resign. But with the emergence of the poison pill, the story goes, staggered boards became more potent than the enacting shareholders anticipated. ${ }^{18: 3}$ While in place, the pill prevents the consummation of a hostile tender offer. The staggered board, in turn, obstructs the main way to get around the pill-a proxy contest-because it takes two consecutive proxy contests to replace a board majority and requires shareholders to elect a raider's nominees without assurance that the company will be taken

179)283 A.2d 852 (Del. Ch. 1971).

1.ill at 855 .

Is! Id. at 854 .

18: See BC\&S, supra note 6 at 899 ("[A] staggered board without a pill is ... ineff ective against a bid, given the unlikelihood that target directors will continue to resist if a bidder has acquired a majority of the target's stock."); Black \& Kraakman, supra note 6. at 562 (same); Gilson, supra note 6, at 781-82 (same).

Ix:3 See BC\&S supra note 6 , at 90)3-25 (arguing that emergence of the poison pill made staggered boards more potent than anticipated); Black \& Kraakman, supra note 6 , at 562 (arguing that the pill does not allow shareholders to vote on the board's decision to reject a takeover bid); see also Robert B. Thompson \& D. Gordon Smith, Toulard a New Theory of the Shareholder Role: "Sacred Space" in Comporate Takeovers, 80 TEx. L. REv. $261,305(2001)$ (noting that the pill makes a hostile takeover prohibitively expensive for potential acquirers). 
over shortly. Although, it is argued, the pill/staggered board combination is more potent than current shareholders desire, ${ }^{1,4}$ few boards give shareholders the opportunity to vote on charter amendments to de-classify the board. Courts should assist shareholders, these commentators argue, by forcing a board to redeem the pill once it has lost an initial proxy context. ${ }^{1 \times \bar{j}}$ The case for legal intervention is arguably strengthened by the fact that Delaware courts are only asked to clean up the problem that they themselves created by judicially sanctioning the innovative poison pill defense: ${ }^{186}$ had they never sanctioned the pill, the staggered board would only have the milder effect that was anticipated, and no judicial intervention would be needed now.

We think that this story understates the significance of staggered boards in pre-pill days. Staggered boards have always served as an entrenchment device against control changes that, ex post, were opposed by the board but favored by a majority of shareholders. Before the advent of the pill, neither the SEC nor commentators thought that staggered boards were toothless. ${ }^{157}$ On the contrary, staggered boards have always been viewed as making it substantially more difficult to replace the board in a proxy contest. As a commentator noted in 1955:

In recent years, the number of corporations having classified directors has increased, perhaps because of the increasing number of contests for control of corporations. Obviously, classification makes it harder to change management and makes it probable that management cannot be changed until after at least two annual meetings of stockholders, unless some of the incumbent directors side with those seeking control. Insurgent stockholders must secure the vote of a majority of the stock represented at two or more annual meetings in order to effectuate control.

1.4 See Black \& Kraakman, supra note 6, at 560 ("Shareholders . . cannot unilaterally accept or reject a takeover bid. They must wait for the board to act . . ..").

${ }_{185}$ See BC\&S, supra note 6 , at 944 (arguing that courts should not allow managers to block a takeover bid after having lost an election on an acquisition offer); Black \& Kraakman, supra note 6, at 561 (same); Gilson, supra note 6, at 8(1)7-18 (same); see also Thompson \& Smith, supra note 183, at 315-19 (describing the "just say no" defense under Delaware law).

1s: We have addressed this point previously. See Kahan \& Rock, sufre note 43, at 9()9-11.

1s: See Disclosure in Proxy and Information Statements; Anti-Takeover or Similar Proposals, SEC. Securities Exchange Act Release No. 15,230, [1978 Transfer Binder] Fed. Sec. L. Rep. (CCH) I 81,748, at Attachment A (Oct. 13, 1978) (permitting classified boards as defensive charter provisions); Leonard D. Adkins, Corporate Democrac) and Classified Directors, 11 BL's. LAW'. 31, 32 (1955) (noting that classification creates obstacles for insurgent stockholders). 
which, of course, materially increases the cost of the proxy fights involved and may well tend to discourage an attack.

When hostile control contests were primarily waged by proxy battles, the entrenching effect of a staggered board was identical to the effect today of a staggered board with a poison pill when hostile tender offers are used. In both cases, the bidcier has to wait a bit longer than a year, or reach a deal with the board. While stockholders in earlier decades who supported board classification may not have anticipated that the poison pill would be invented later, they did choose to codify one of the strongest defensive measures that was available to their directors at that time. And even when hostile tender offers became the dominant mode for effecting control changes, the notion that bidders consummate the tender offer and hope for the board to resign strikes us as divorced from reality. ${ }^{i n !}$ It is far from clear that any bidder would be willing (or that any lender would permit a bidder) to spend huge amounts of money to buy stock with a hostile board still in control."

This being said, it is correct that a staggered board combined with a pill is a stronger barrier than a staggered board without a pill. Adoption of a staggered board in the pre-pill, post-proxy contest davs may thus reflect a desire for a moderate degree of entrenchment, where a staggered board by itself is "just right," but a staggered board with a pill (or neither a staggered board nor a pill) is too cold or too hot. The validation of a pill, in other words, is indeed one of these expected, unexpected surprises. But does that provide a case for legally neutralizing the entrenchment effect of staggered boards?

It is hard to conceive of a judicially crafted rule that would treai companies that adopted staggered boards in the pre-pill era differently from those that adopted them in the post-pill era. As to companies that went public or adopted staggered boards during the post-pill era, there is obviously no argument for changing the rules based on

18\$ Adkins, sufra note 187, at 31, 32.

1.'s: Telephone Conversation with Arthur Fleischer, Jr.. Senior Partner, Fried, Frank, Harris, Shriver \& Jacobson (2(2)()으)

1:11 To be sure, when faced with a hostile bid that has obtained shareholder support, a company with a staggered board may decide not to fight it out. Rather, the board will try to negotiate the terms of surrender. This, of course, remains true todar for most companies with staggered boards and poison pills, as illustrated by the smal number of failed hostile bids. Sep supra text accompanving notes 121-25 (noting a low failure rate of hostile bids involving companies with staggered boards). 
changed circumstances. ${ }^{191}$ But even with respect to firms that adopted staggered boards in the pre-pill era, the case for judicial intervention to render staggered boards impotent is ambiguous. If the percentage of post-pill IPO companies with staggered boards is an approximate measure of the overall percentage for which staggered boards plus pills are advisable, that combination would be appropriate for many companies that adopted a staggered board before the advent of the pill. Moreover, there is evidence that adaptive devices-independent directors and stock options, in particular-have greatly reduced the extent to which pills are used for pernicious purposes. ${ }^{1+2}$ Thus, there is no sufficient basis for a wholesale judicial neutralization of the entrenchment effect of the staggered board combined with a poison pill."

\section{CONCILSION}

Constitutions constitute a polity and create and entrench power. A corporate constitution-the gorernance choices incorporated in state law and the certificate of incorporation-resembles a political constitution. Delaware law allows parties to create corporations, to endow them with perpetual life, to assign rights and duties to "citizens" (directors and shareholders). to adopt structures of governance, and to entrench those structures.

191 This does not mean that courts should ignore a shareholder vote to replace a third of a staggered board. As we have discussed in an earlier article, such a vote may well bear on the judicial application of the Unocal test. See Kahan \& Rock, supro note 43 , at 911-15 (arguing that the shareholder vote should be a factor in the court's enhanced scrutiny review of a board's decision to "just say no").

1"): See eg., id. at $887-99$ (arguing that the poison pill-a potentially pernicious tool-did not actually yield the expected effects).

A stronger case could be made for legislative bailout. A legislative response could be tailored to minimize the extent io which it would undermine commitments that were working as anticipated. First, a legislative bailout could be confined to companies that have adopted staggered boards in the pre-pill era. Second, it could be structured in such a way as to reduce trausaction costs and minimize the loss of commitment value for the companies that have adopted a staggered board pre-pill and want to retain the commitment embedded in it. For example, a statute could require that companies with pre-pill staggered boards propose a chater amendment to repeal the staggered board within three years af ter shareholder sadopt a resolution calling for such an amendment. Such a regime would impose costs associated with a charter amendinent only on select pre-pill companies. Morester, as the board would choose the timing of the vote on the staggered board, the rote would be conducted outside the context of a specific acquisition offer and thus reflect a choice on whether to entrench board power, rather than on whether to aclopt a specific acquisition offer. 
In this Article, we have argued that the decision to endow directors with significant power over acquisitions is a constitutional choice of governance structure. We then argued that it is, on theoretical and empirical grounds, a perfectly intelligible choice: shareholders reasonably might opt for board veto in order to enable a board to employ selling strategies more effectively and thus increase the premium shareholders receive when the company is sold. Such a decision is a kind of precommitment whereby shareholders, by binding themselves ex ante, may be able to improve their collective position ex post.

Once one understands the nature of shareholders' intertemporal choice, and why shareholders might plausibly opt for it, it should not be surprising if cases arise in which the precommitments bind, and shareholders, ex post, might wish to be relieved of the consequences of their choice. That is the necessary consequence, and indeed the very purpose, of a precommitment. A court's excessive willingness, ex post, to rewrite the bargain to relieve a party on the grounds of "surprise" undermines the possibility of precommitment ex ante. 